\title{
Estradiol-induced proliferation of papillary and follicular thyroid cancer cells is mediated by estrogen receptors $\alpha$ and $B$
}

\author{
AKHILESH KUMAR ${ }^{1 *}$, CAROLYN M. KLINGE ${ }^{2,3^{* \#}}$ and RICHARD E. GOLDSTEIN ${ }^{1,3 \#}$ \\ Departments of ${ }^{1}$ Surgery and ${ }^{2}$ Biochemistry and Molecular Biology, ${ }^{3}$ Center for Genetics and Molecular Medicine, \\ University of Louisville School of Medicine, Louisville, KY 40292, USA
}

Received August 31, 2009; Accepted December 14, 2009

DOI: 10.3892/ijo_00000588

\begin{abstract}
Premenopausal women are at highest risk for papillary and follicular thyroid carcinoma, implicating a role for estrogens in thyroid cancer. The expression of estrogen receptors $\alpha$ and $B(E R)$, the effects of estradiol $\left(E_{2}\right)$, selective estrogen receptor modulators (SERMs) 4-hydroxytamoxifen and raloxifene, and ER subtype selective agonists were examined in NPA87 and KAT5 papillary and WRO follicular thyroid carcinoma cell lines. All three thyroid cancer cell lines expressed full-length ER $\alpha$ and ER $\beta$ proteins with cytoplasmic localization that was unaffected by $\mathrm{E}_{2}$. ICI 182,780 (Fulvestrant, an ER antagonist), and inhibitors of non-genomic $\mathrm{E}_{2}$-activated MAPK and PI3K signaling blocked $\mathrm{E}_{2}$-induced cell proliferation. SERMs acted in a cell line-specific manner. No $E_{2}$-induced estrogen response element (ERE)-driven reporter activity was observed in transiently transfected thyroid cancer cells. However, $\mathrm{E}_{2}$ increased transcription of established endogenous $\mathrm{E}_{2}$-target genes, i.e., cathepsin D in WRO and cyclin D1 in both KAT5 and WRO cells in an ER-dependent manner as validated by inhibitor and siRNA experiments. In contrast, $\mathrm{E}_{2}$ did not increase progesterone receptor expression in the thyroid cancer cell lines. $\mathrm{E}_{2}$ stimulated phosphorylation of ERK1/2 in KAT5 and WRO cells and siER $\alpha$ or siERß inhibited $\mathrm{E}_{2}$-induced ERK phosphorylation. Expression of the putative membrane estrogen receptor GPR30 was detected in WRO, but not NPA87 or KAT5 cells. GPR30 expression was lower in WRO than MCF-7 human breast cancer cells. Overall, these findings suggest $\mathrm{E}_{2}$-mediated thyroid cancer
\end{abstract}

Correspondence to: Dr Carolyn M. Klinge, Department of Biochemistry and Molecular Biology, University of Louisville School of Medicine, Louisville, KY 40292, USA

E-mail: carolyn.klinge@louisville.edu

*Contributed equally

"Jointly directed this work

Key words: thyroid cancer (human), estrogens, SERMs, estrogen receptor, cathepsin D, cyclin D1 cell proliferation involves ER $\alpha$ and ERß transcriptional and non-genomic signaling events.

\section{Introduction}

Thyroid cancers are among the most common neoplasms affecting the endocrine system (1-4). In 2007, there were 33,550 new thyroid cancer cases in the United States (NCI, http://seer.cancer.gov/). Histological characterization of thyroid tumors indicated that $88 \%$ were papillary, $9 \%$ follicular, and $3 \%$ poorly differentiated thyroid cancer (5). Thyroid cancer is $\sim 2.7$ times more frequently diagnosed in reproductive age women compared to similar aged men $(5,6)$. Further, the incidence of all types of thyroid cancer decreases after menopause (7). An increased risk of thyroid cancer has been documented in women who take estrogen for gynecological reasons (8). Together these studies indicate that the gender difference in thyroid cancer incidence may involve estrogens $(4,9)$.

A number of peptide hormones, growth factors, and steroids regulate the proliferation and function of normal and neoplastic thyroid tissue (10-12). Epidemiological studies have indicated estrogens promote growth in number of tissues (13). Estrogens regulate cell proliferation by binding to specific receptors: estrogen receptors $\alpha$ and $\beta$ (ER $\alpha$ and ER $\beta)$ (14). ER $\beta$ shares high homology with ER $\alpha$ and these two ER subtypes differentially regulate gene expression and cell proliferation in a cell type- and gene-specific manner with ER $\alpha$ considered 'proliferative' whereas ERß is 'antiproliferative' (15).

In the classical, genomic estrogen signaling pathway, estradiol $\left(\mathrm{E}_{2}\right)$-activated $\mathrm{ER} \alpha$ translocates to the nucleus, dimerizes, and binds to the 15-bp palindromic estrogen response element (ERE) or interacts with other transcription factors in target genes, recruits coactivators, and stimulates gene transcription thereby promoting cell proliferation (16). $\mathrm{ER} \alpha$ interacts with a number of coactivators and corepressors in a ligand-dependent manner (16). The subcellular localization of ER $\alpha$ is cell-type and hormonal milieu-dependent. For example, in some breast cancer cells, ER $\alpha$ interacts with metastasis-associated protein-1 (MTA1), a component of histone deacetylase and nucleosome remodeling complexes (HDAC and NURD) and represses ER $\alpha$ activity (17). A short variant of MTA1 called MTA1s, containing a novel 33 aa insert, binds and sequesters $\mathrm{ER} \alpha$ in the cytoplasm, thus 
blocking ER $\alpha$-mediated transcription (18). Another mechanism of estrogen action is more rapid and is termed 'non-genomic' or 'membrane-initiated' because it involves $\mathrm{E}_{2}$ activation of plasma membrane associated ER $\alpha$ or ERß and leads to rapid activation of intracellular signaling pathways, e.g., ERK1/2 and PI3K/Akt (19). Non-genomic estrogen action is mediated by $E R \alpha$ or ERß interactions with signaling proteins in caveolae (20). GPR30 is a novel membrane estrogen receptor that also activates ERK1/2 and PI3K/Akt signaling, although its role in estrogen action remains controversial (20-23).

The expression of ER has been demonstrated in normal and neoplastic thyroid tissue by mRNA (24), immunohistochemistry (IHC), estradiol $\left(\mathrm{E}_{2}\right)$ binding assays $(4,13,25)$, enzyme-immunoassays (26), and immunoblots (9). ER $\alpha$ expression was relatively higher in the thyroid tumors compared to normal thyroid tissue (4). Despite these studies, only a few investigators have examined the function of estrogens or selective ER modulators (SERMs), e.g., tamoxifen and raloxifene, in thyroid cancer cells. These studies demonstrated that $\mathrm{E}_{2}$ and the $\mathrm{ER} \alpha$-selective agonist PPT stimulated whereas the ERß-selective agonist DPN inhibited KAT5 papillary thyroid cancer cell proliferation $(27,28)$.

Previous studies reported that $\mathrm{E}_{2}$ rapidly activates ERK1/2 in thyroid cancer cells through the non-genomic estrogen signaling pathway mediated by the membrane estrogen receptor GPR30 (22). $\mathrm{E}_{2}$-activation of this pathway increased WRO follicular thyroid cancer cell proliferation by increasing c-fos, cyclin A, and cyclin D1 expression (22). These and other recent data indicate that the signaling mechanisms explaining estrogen action are far more complex than initially appreciated because it involves multiple forms of estrogen receptors $(22,29)$.

Although considerable progress has been made in our understanding of the molecular mechanisms of thyroid cancer in recent years, the specific nature of ER signaling leading to increased cell proliferation is poorly understood. The objective of this study was to determine the effect of $E_{2}$ and other ER ligands in different types of thyroid cancer cells. We compared the proliferative and transcriptional responses of follicular (WRO) and papillary (NPA87 and KAT5) thyroid cancer cells. Using siRNA specific for $\mathrm{ER} \alpha$ and ERß, we examined the effect of $\mathrm{E}_{2}$ on the expression of ER-regulated gene targets cathepsin D (CTSD) and cyclin D1 (CCND1). Our results indicate that $\mathrm{E}_{2}$ increases the proliferation of thyroid cancer cells through mechanisms independent of the classical genomic activity of ER.

\section{Materials and methods}

Reagents. Estradiol ( $\left.\mathrm{E}_{2}\right)$, Raloxifene (RAL), and 4-hydroxytamoxifen (4-OHT) were purchased from Sigma-Aldrich Corp. (St. Louis, MO, USA). ICI 182,780 (ICI), 4,4',4'-(4-propyl[1H]-pyrazole-1,3,5-triyl)trisphenol (PPT, an ER $\alpha$-selective agonist), and 2,3-bis(4-hydroxyphenyl)-propionitrile (DPN, an ER $\beta$-selective agonist) were purchased from Tocris Chemicals (Ellisville, MO, USA). The selective ER $\alpha$ agonist/ ERß antagonist R,R-tetrahydrochrysene (R,R-THC) was a generous gift from Dr John A. Katzenellenbogen (30). PD98059, pertussis toxin (PTX), and Wortmannin were purchased from Sigma-Aldrich. $\mathrm{E}_{2}, 4-\mathrm{OHT}$, and R,R-THC were dissolved in ethanol and ICI, PPT, and DPN were dissolved in dimethylsulfoxide (DMSO).

Cell culture. Human papillary thyroid carcinoma cells (NPA87) were generously provided by Dr James A. Fagin (Memorial Sloan-Kettering Cancer Center, New York, NY). Human papillary thyroid carcinoma cells (KAT5) and follicular carcinoma cells (WRO and TPC1) were a kind gift from Dr Kenneth B. Ain (University of Kentucky Medical Center, Lexington, KY). These cell lines were grown in RPMI-1640 with $10 \%$ fetal calf serum, $2 \mathrm{mM} \mathrm{L-glutamine,} \mathrm{and} 50 \mathrm{U} / \mathrm{ml}$ of penicillin and streptomycin. For WRO cells, 1x non-essential amino acids and $1 \mathrm{mM}$ sodium pyruvate (Mediatech Inc., Herndon, VA) were added to the medium. FTC133 cells were generously provided by Dr Electron Kebebew (The University of California, San Francisco, CA) and were routinely cultured in DMEM/F12 (Mediatech) with $10 \%$ fetal bovine serum (FBS), $200 \mathrm{mM}$ L-glutamine, $10 \mathrm{mIU} / \mathrm{ml}$ human thyrotropin, and $10 \mu \mathrm{g} / \mathrm{ml}$ insulin (31). All cell cultures were maintained at $37^{\circ} \mathrm{C}$ and $5 \% \mathrm{CO}_{2}$ atmosphere in a humidified cell culture chamber with growth medium changed each 3-4 days. Breast cancer cell line MCF-7 (expressing wild-type ER $\alpha$ ) was used as a positive control in many experiments. MCF-7 cells were grown in IMEM supplemented with penicillin and streptomycin and 10\% FBS. At 70-80\% confluence of cells, the growth medium was replaced with hormone and phenol red-free IMEM medium with $2 \%$ dextran charcoal stripped FBS (DCC-FBS) for $48 \mathrm{~h}$ before stimulation with $\mathrm{E}_{2}$ or other ER ligands. FTC133 cell experiments were carried out in H5 media: phenol red-free DMEM/F12 supplemented with $2 \%$ DCC-FBS, $200 \mathrm{mM}$ L-glutamine, $10 \mu \mathrm{g} / \mathrm{ml}$ insulin, $5 \mu \mathrm{g} / \mathrm{ml}$ transferrin, $10 \mathrm{mg} / \mathrm{ml}$ somatostatin, $2 \mathrm{ng} / \mathrm{ml}$ gly-his-lys, and $360 \mathrm{pg} / \mathrm{ml}$ hydrocortisone (31). For the indicated experiments, $100 \mathrm{nM}$ ICI, 4-OHT, or R,R-THC was added $1 \mathrm{~h}$ before addition of $10 \mathrm{nM} \mathrm{E}_{2}$. For other studies, cells were preincubated for $3 \mathrm{~h}$ with $50 \mu \mathrm{M}$ PD98059 (MEK1 inhibitor), $100 \mathrm{nM}$ Wortmannin (PI3K inhibitor), or $100 \mathrm{ng} / \mathrm{ml}$ pertussis toxin (PTX, a $\mathrm{G} \alpha$ inhibitor) prior to adding $10 \mathrm{nM} \mathrm{E}_{2}$ for the indicated time.

Cell proliferation assay. For quantitative proliferation assays, 2,000 cells were seeded in 96-well plates in regular growth medium. Cells were incubated in medium containing $2 \%$ DCC-FBS for $48 \mathrm{~h}$, prior to treatment with $\mathrm{E}_{2}, 4-\mathrm{OHT}$, ICI, raloxifene, DPN, PPT, and R,R-THC as indicated in the text and figures with the medium containing the treatment renewed every $48 \mathrm{~h}$. Cell proliferation was measured using the BrdU Cell Proliferation kit (Roche, Indianapolis, IN) according to the manufacturer's specifications. Quadruplicates were performed for each treatment. Experiments were performed at least three times and the relative proliferation values are given in comparison to EtOH/DMSO (vehicle).

Transient transfection and luciferase assays. KAT5, NPA87, and WRO cells $(15,000$ cells/well) were plated into 24-well plates with $500 \mu 1$ of regular growth medium. After overnight incubation, the growth medium was replaced with serumfree medium for transfection using FuGENE 6 reagent as 
recommended by the manufacturer (Roche). Each well was transfected with a mixture containing $250 \mathrm{ng}$ of pGL3-2EREpro-luciferase reporter plasmid (32) and $5 \mathrm{ng}$ of pRL-tk, Renilla luciferase reporter from Promega, and $100 \mathrm{ng}$ or pcDNA3.1 (Promega), ER $\alpha$, or ERß expressing plasmids (33). Eighteen hours post-transfection, the cells were treated with $\mathrm{EtOH}$, $10 \mathrm{nM} \mathrm{E}_{2}, 100 \mathrm{nM}$ ICI, $100 \mathrm{nM}$ 4-OHT, $100 \mathrm{nM}$ RAL, $10 \mathrm{nM}$ DPN, or $10 \mathrm{nM}$ PPT for $30 \mathrm{~h}$. Cells were lysed using Promega passive lysis buffer. Firefly and Renilla luciferase activities were measured with the dual luciferase kit (Promega, Madison, WI) according to the manufacturer's recommendations in a Plate Chameleon luminometer (Hidex Oy, Finland) (34). Firefly luciferase values were normalized to Renilla luciferase activity. The normalized relative light unit values obtained in EtOH-treated MCF-7 cells was set as 1 . Experiments were repeated at least three times.

Small inhibitory RNA (siRNA) transfection. Cells were plated in 6-well plates in antibiotic-free RPMI medium. For the siRNA studies, On-Target plus SMARTpool of siRNA against ER $\alpha$ (L-003401-00), or ERß (L-003402-00) were purchased from Dharmacon Tech (Lafayette, CO). As a negative control, the universal negative siRNA was purchased from Invitrogen. siRNAs were transfected into the cells according to the manufacturer's instructions. Briefly, cells were transfected with 100 nM siRNA duplexes using DharmaFECT 1 (Dharmacon Tech). After overnight incubation, the cells were then grown for 2 days in culture medium supplemented with $3 \%$ DCCFBS. Cells were harvested at 48 or $72 \mathrm{~h}$ after transfection and processed for RNA and protein analysis, respectively. To allow the same total time of siRNA transfection $(48 \mathrm{~h})$, the transfected cells were treated with $\mathrm{E}_{2}$ or ICI at $39,42,45$ and $47 \mathrm{~h}$ as needed for 9, 6, 3, and $1 \mathrm{~h}$ of $\mathrm{E}_{2}$ treatment. RNA was isolated using RNeasy Mini Kit (Qiagen Inc., Valencia, CA). The ER $\alpha$ and ERß mRNA and protein expression levels were analyzed using q-RT-PCR and Western blotting, as described below.

Preparation of whole cell extracts (WCE) and Western blotting. Thyroid cancer cells were washed with cold PBS and were lysed in RIPA buffer (150 mM NaCl, $10 \mathrm{mM}$ Tris, pH 7.20, $1 \%$ SDS, $1 \%$ Nonidet P-40, $0.25 \%$ Na-deoxycholate, $5 \mathrm{mM}$ EDTA, $2 \mathrm{mM} \mathrm{NaF}, 1 \mathrm{mM} \mathrm{VaPO}_{3}$ ), and protease inhibitor cocktail (Roche), $100 \mathrm{mM}$ PMSF and $1 \mathrm{mM} \mathrm{Na} \mathrm{VO}_{4}$ were added to lysis buffer before adding to the cells. Lysed cells were sonicated using Branson 250 Sonicator (Branson, Danbury, CT) three times at 20 amplitude for $15 \mathrm{sec}$ on ice and were sedimented at 12,000 rpm for $30 \mathrm{~min}$. Protein concentrations in WCE were determined using Bio-Rad Detergent Compatible (DC) protein assay (Hercules, CA, USA).

WCE (50 $\mu \mathrm{g}$ of protein) were mixed with $4 \mathrm{X}$ electrophoresis sample buffer (SB) and boiled for $5 \mathrm{~min}$ prior to separation on a $10 \%$ polyacrylamide gel. The proteins were transferred to a PVDF membrane (Whatman, Florham Park, $\mathrm{NJ})$. The membrane was blocked for $1 \mathrm{~h}$ in $5 \%$ non-fat dried milk in TBS-Tween at room temperature (RT). The membranes were then incubated with the following primary antibodies overnight at $4^{\circ} \mathrm{C}$ : HC-20 (1:200, rabbit polyclonal raised against ER $\alpha \mathrm{C}$-terminal, Santa Cruz Biotechnologies,
Santa Cruz, CA), AER320 (1:150, mouse monoclonal antibody generated against ER $\alpha 495$ to 595 C-terminal (Neomarkers/ Labvision, Freemont, CA), H150 (1:150 rabbit polyclonal antibody raised against human ERß N-terminal 1-150 amino acids (Santa Cruz), MTA1 (1:100, mouse monoclonal, SigmaAldrich). The membranes were then incubated in a horseradish peroxidase (HRP)-conjugated goat anti-rabbit or anti-mouse secondary antibodies, or rabbit anti-goat secondary antibody (Amersham Biosciences, Piscataway, NJ) at 1:5,000 dilutions for $1 \mathrm{~h}$ at room temperature. Following ER or other primary protein target detection, the membranes were stripped and re-probed with an antibody to $ß$-actin (Cell Signaling) for normalization. The protein bands were detected by chemiluminescence (Pierce Biotechnology, Inc., Rockford, IL). Most of the Western blot signals were captured using Kodak BioMax MS film (Eastman Kodak, Rochester, NY). In some cases, the Western signal was recorded with a FluorChem FC2 (Alpha Innotech, San Leandro, CA). The molecular weights (MW) of the proteins were estimated by comparing migration against the dual color MW standard (Invitrogen, Carlsbad, CA). Sizes and density of immunoreactive protein bands were quantified by densitometry using Un-Scan-It (Silk Scientific, Orem, UT). Relative ER $\alpha$ or ERß protein expression was normalized by $\beta$-actin within each blot.

Immunofluorescence staining. Cells were allowed to grow on sterile glass cover slip and were maintained in $2 \%$ serum-free medium for 3 days and then were treated with $10 \mathrm{nM} \mathrm{E}_{2}$ for $45 \mathrm{~min}$. The cells were fixed in $4 \%$ paraformaldehyde for $30 \mathrm{~min}$. After paraformaldehyde removal, the cells were washed three times with PBS, and were permeabilized with $0.05 \%$ Triton X-100 in PBS for $30 \mathrm{~min}$. Then the cells were incubated with $5 \%$ bovine serum albumin for 60 min to block the non-specific binding sites. Immunocytochemical staining for $\mathrm{ER} \alpha$ and $E R ß$ was performed using AER320 and H150 as the primary antibodies, respectively. The secondary antibodies used for fluorescence detection were Alexa Fluor 488 goat anti-mouse IgG for ER $\alpha$ and Alexa Fluor 568 goat anti-rabbit IgG for ERß (Invitrogen). The cells were washed 3 times with PBS and once with deionized water before the cover slip were mounted onto a slide containing $10 \mu \mathrm{l}$ of Vectashield mounting media containing DAPI for staining DNA (Vector Laboratories, Burlingame, CA). The fluorescence were detected in Olympus iX50 inverted fluorescence microscope and the images were captured using QCapture (Quantitative Imaging Corp., Surrey, BC, Canada) and the captured images were color coded using Northern Eclipse software (Empix Imaging, Inc. Cheektowaga, NY). All the images were captured at magnification $\mathrm{x} 200$ with exposure time of $0.5 \mathrm{sec}$ for the blue, $3 \mathrm{sec}$ for the red, and $6 \mathrm{sec}$ for the green fluorescent dye.

Q-PCR for progesterone receptor (PR), cathepsin D (CTSD), cyclin D1 (CCND1), and GPR30. Total RNA was isolated from untreated cells or cells after 1, 3, 6 and $9 \mathrm{~h}$ following vehicle [ethanol (EtOH)], $10 \mathrm{nM} \mathrm{E}_{2}$, or $100 \mathrm{nM}$ ICI treatment using TRIzol reagent (Invitrogen). The quality and quantity of RNA was assessed by measuring the A260/A280 ratio using a NanoDrop spectrophotometer (NanoDrop Technologies, Wilmington, DE). Total RNA ( $3 \mu \mathrm{g})$ was converted to 
cDNA using a high capacity cDNA reverse transcription (RT) kit (Applied Biosystems, Foster City, CA) according to the procedure provided by the manufacturer. TaqMan Gene Expression Assays were used to quantitate mRNA levels for progesterone receptor (Hs00172183_m1), cathepsin D (Hs00157201_m1), cyclin D1 (Hs00277039_m1), GPR30 (Hs00173506_m1). Quantitative real-time PCR (Q-PCR) was performed in a 7300 ABI Real-Time System (Applied Biosystems). Relative target gene expression was determined using the $\Delta \mathrm{C}_{\mathrm{t}}$ method employing the formula: relative expression $=$ $2^{-[\Delta \mathrm{Ct} \text { sample - } \Delta \mathrm{Ct} \text { control] }}$ (35) where $\mathrm{Ct}$ refers to the threshold cycle, sample indicates the gene of interest and control indicates the endogenous house-keeping gene (18S). Within each experiment, samples were run in triplicate and the experiments were repeated at least three times.

Statistical analysis. Statistical analyses were performed using Prism 4.0 (GraphPad Software Inc. San Diego, CA) for One way ANOVA followed by the Student-Newman-Keuls test, or Student's t-test. P-values $<0.05$ were considered statistically significant.

\section{Results}

$E_{2}$ and SERMs affect thyroid cancer cell proliferation. To address the role of estrogens in the proliferation of the three major types of thyroid cancer, three thyroid cancer cell lines representing papillary (KAT 5 and NPA87) and follicular (WRO) cancers were incubated with increasing concentrations of $\mathrm{E}_{2}$ and fixed concentrations of the SERMs 4-OHT and RAL or the selective estrogen receptor down-regulators (SERD) ICI 182,780 (Faslodex/Fulvestrant, ICI), alone or in combination. Cell proliferation was measured by BrdU incorporation (Fig. 1). $\mathrm{E}_{2}$ increased KAT5, NPA87, and WRO thyroid cancer cell proliferation in a concentration-dependent manner. The KAT5 data are consistent with a previous report (27).

4-OHT, the classical SERM with its cell line-specific ER antagonist/agonist activity (36), increased proliferation of KAT5 and WRO cells, but not NPA87. The effect of the SERM RAL was also examined because it has less agonist activity than 4-OHT (37). Like 4-OHT, RAL stimulated WRO cell proliferation, but had no effect in KAT5 or NPA87 cells. ICI, the SERD considered as a pure antiestrogen (38), had no significant effect on cell proliferation, but blocked $\mathrm{E}_{2}$-induced cell proliferation in all 3 thyroid cancer cell lines, indicating that the effect of $\mathrm{E}_{2}$ on cell proliferation is ER-mediated (Fig. 1). Neither 4-OHT nor ICI inhibited basal proliferation, reflecting the modest effect of $\mathrm{E}_{2}$ on thyroid cell proliferation, consistent with previous reports $(27,28)$. When combined with $\mathrm{E}_{2}$, 4-OHT inhibited $\mathrm{E}_{2}$-induced proliferation in all 3 thyroid cancer cell lines, but RAL only inhibited $\mathrm{E}_{2}$-induced BrdU incorporation in NPA87 cells, similar to 4-OHT (Fig. 1B).

Because non-genomic ER activation leads to cell proliferation $(28,39)$, the effect of inhibitors of non-genomic $\mathrm{E}_{2}$ signaling were tested in the 3 thyroid cancer cell lines. Cells were preincubated with each inhibitor and then $\mathrm{E}_{2}$ was added. PD98059 (MEK1 inhibitor) inhibited basal proliferation of
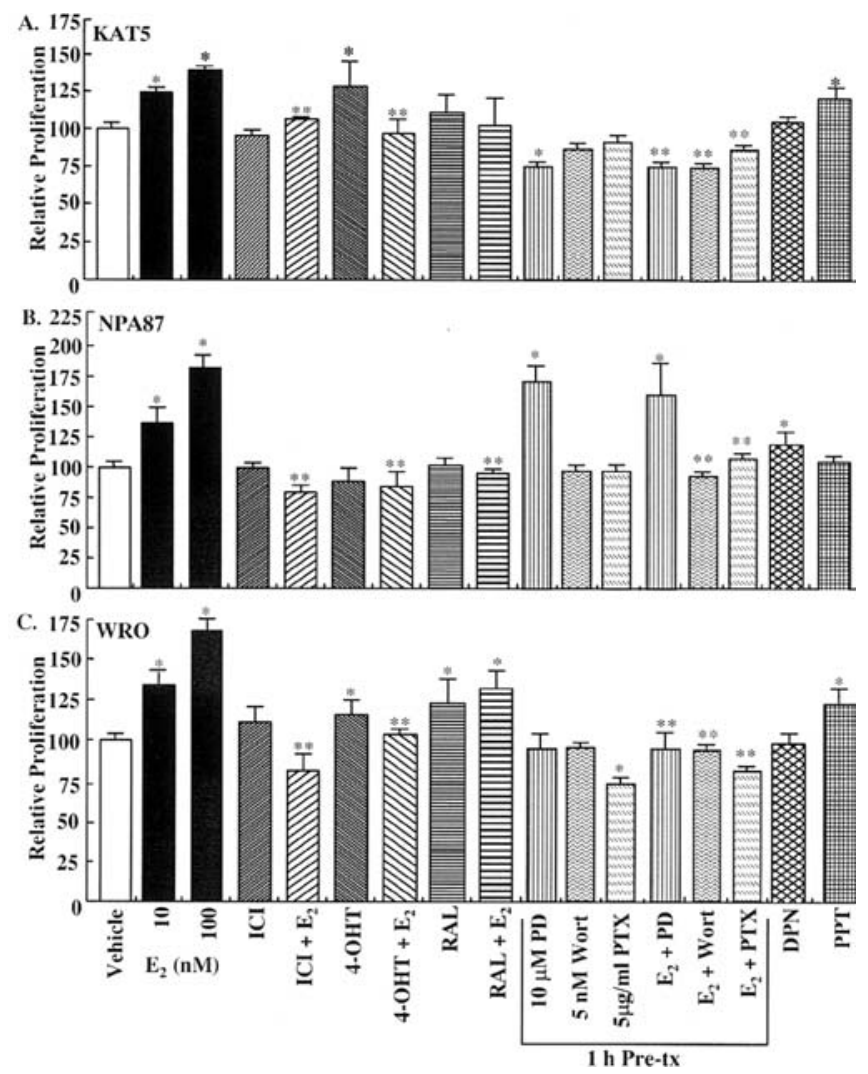

Figure 1. $\mathrm{E}_{2}$ increases thyroid cancer cell proliferation. The effect of the indicated concentrations of $\mathrm{E}_{2}$ and $100 \mathrm{nM}$ ICI, $100 \mathrm{nM} 4-\mathrm{OHT}, 100 \mathrm{nM}$ RAL, $10 \mathrm{nM}$ DPN, $10 \mathrm{nM}$ PPT, alone or in combination with $10 \mathrm{nM} \mathrm{E}_{2}$ on the proliferation of KAT5 (A), NPA87 (B), and WRO (C) thyroid cancer cells was determined after $48 \mathrm{~h}$ of treatment by assaying BrdU incorporation as described in Materials and methods. Where indicated, cells pre-incubated for $3 \mathrm{~h}$ with the non-genomic pathway inhibitors at the concentrations shown. Data were normalized to the vehicle (EtOH/DMSO) in each experiment. Values are $\%$ of vehicle control and are the mean \pm SEM of at least 5 independent experiments. *Significantly different from vehicle (EtOH) or ${ }^{* *} 10 \mathrm{nM} \mathrm{E} \mathrm{E}_{2}$ within each cell line, respectively $(\mathrm{p}<0.05)$.

KAT5 and stimulated basal proliferation in NPA87 cells. PD98059 inhibited $\mathrm{E}_{2}$-induced proliferation of KAT5 and WRO cells. Wortmannin (PI3K inhibitor) inhibited $\mathrm{E}_{2}$-induced proliferation of KAT5, NPA87, and WRO cells. PTX (a G $\alpha$ inhibitor) inhibited $\mathrm{E}_{2}$-induced proliferation of all 3 thyroid cancer cell lines. Together with the SERM and ICI data, these data indicate that the $\mathrm{E}_{2}$-induced proliferation of KAT5 and WRO involves ER and MAPK, PI3K, and G-protein coupled pathways. In contrast, while clearly involving ER, PI3K, and G-protein pathways, the MAPK does not appear to play a role in $\mathrm{E}_{2}$-induced proliferation of NPA87 cells.

To address which ER subtype might be mediating the observed effects of $E_{2}$ and SERMs on cell proliferation, cells were treated with the ER $\alpha$ agonist PPT (40), ERß agonist DPN (41), or the ER $\alpha$-selective agonist/ERß-selective antagonist R,R-THC (30) (Fig. 1). DPN increased NPA87 cell proliferation (Fig. 1B), suggesting a role for ERß in the $E_{2}$ effect, but not in KAT5 and WRO (Fig. 1A and C) cells. PPT increased KAT5 and WRO cell proliferation (Fig. 1A and C), suggesting involvement of ER $\alpha$ in the $\mathrm{E}_{2}$ effect. R,R-THC increased cell proliferation in all the three cell lines (Fig. 1), 
A. ER $\alpha$ AER320

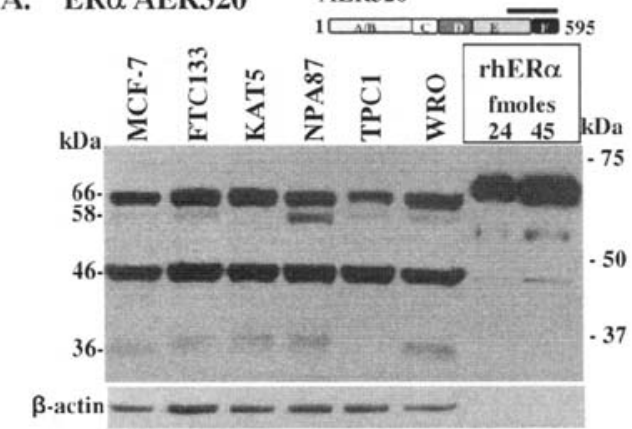

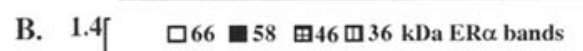

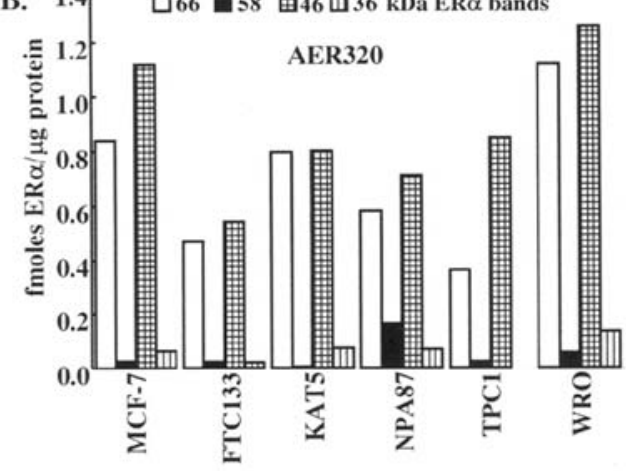

C. $\mathrm{ER} \alpha \mathrm{HC}-20$

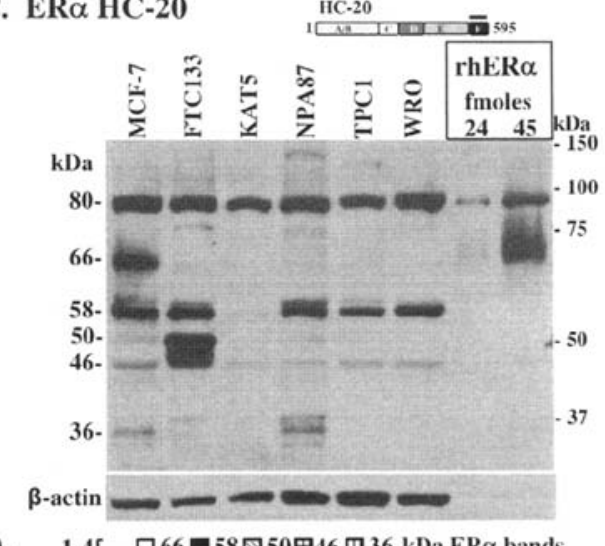

D.

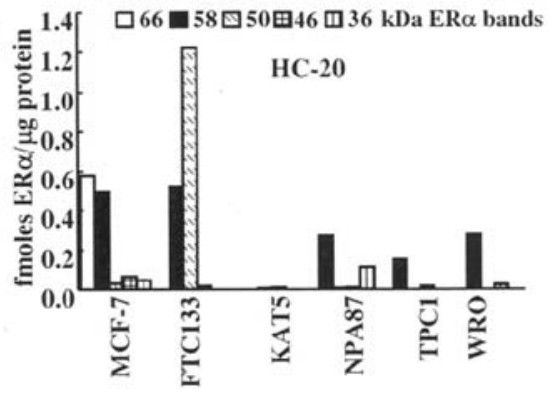

Figure 2. Thyroid cancer cells express ER $\alpha$. The expression of ER $\alpha$ was examined by Western blotting using $50 \mu \mathrm{g}$ of WCE protein from the indicated cell lines using ER $\alpha$ monoclonal AER320 (A) or polyclonal HC-20 (C) antibodies as described in Materials and methods. The indicated fmoles of recombinant human (rh) ER $\alpha$ were included as a control. The membrane was stripped and reprobed for $\beta$-actin. The epitopes recognized by each ER $\alpha$ antibody are indicated by the black bar above the E-F domains in the ER $\alpha$ diagram provided at the top right (A and C). The migration of molecular weight (MW) standards is indicated at the right $(\mathrm{kDa})$. The MW sizes of the immunoreactive ER $\alpha$ bands, indicated at the left, were estimated as described in Materials and methods. The bar graphs below each Western blotting (B and D) are a quantitation of the data in each blot. ER $\alpha$ expression was normalized to 3 -actin as described in Materials and methods. These data are representative of at least five separate Western blots that show similar patterns of ER $\alpha$ expression.

perhaps reflecting its ER $\alpha$-agonist activity (30), and blocked the $\mathrm{E}_{2}$-induced proliferation of NPA87 and WRO (data not shown), but not in KAT5 cells. The inhibition of $\mathrm{E}_{2}$-induced proliferation by $\mathrm{R}, \mathrm{R},-\mathrm{THC}$ in NPA87 and WRO suggests a role for $E R ß$ in mediating $E_{2}$-induced proliferation these cell lines. We also studied the effect of $\mathrm{E}_{2}$ on the growth of FTC133 and TPC1 follicular and papillary thyroid cancer cell lines, respectively, and found them to be non-responsive to $E_{2}$ or any of the SERMs (data not shown).

Expression of ERa and ER $\beta$. To determine the expression of ER subtypes in the three thyroid cancer cell lines, Western blots were performed (Fig. 2). In addition, we examined ER expression in FTC133 and TPC1 thyroid cancer cells. We used MCF-7 human breast cancer cells as a positive control since ER $\alpha$ and ERß are expressed in these cells $(34,42,43)$. Using a monoclonal ER $\alpha$ antibody AER320 which recognizes an epitope in the C-terminus (44), the expression of full length wild-type ER $\alpha 66$ and bands corresponding to the MW of the ER $\alpha 46$ and ER $\alpha 36$ splice variants (42) were detected in MCF-7, FTC133, KAT5, NPA87, TPC1, and WRO cells (Fig. 2A). An additional band of $58 \mathrm{kDa}$ was detected in NPA87, with lower amounts in MCF-7, FTC133, TPC1, and WRO cells (Fig. 2A). ER $\alpha 46$ is the predominant splice variant detected in all cell lines (Fig. 2A). Different MW bands for ER $\alpha$ were observed using polyclonal antibody HC-20, epitope shown in Fig. 2C, compared to those identified by AER320, despite the fact that the epitope for each antibody is the $\mathrm{ER} \alpha \mathrm{C}$ terminus. The full length ER $\alpha 66$ was not detected in any of the thyroid cancer cell lines with $\mathrm{HC}-20$, but it was detected in MCF-7 cells. In agreement with the data in Fig. 2A, the $58-\mathrm{kDa} \mathrm{ER} \alpha$ band was prominent in MCF-7, FTC133, NPA87, TPC1, and WRO cells, but weakly expressed in KAT5 cells (Fig. 2C). An $\sim 50 \mathrm{kDa} E R \alpha$ band was prominent in FTC133 cells. The 46-kDa ER $\alpha$ band was weakly recognized by the HC-20 antibody in all cell lines except FTC133 (Fig. 2C). A 36-kDa ER $\alpha$ band was observed in all cells except KAT5, TPC1, and WRO (Fig. 2C). Previous studies identified ER $\alpha 36$ in breast cancer cells and tumors as a dominant negative ER $\alpha$ splice variant that localizes to the plasma membrane $(45,46)$. The quantification of ER $\alpha$ using the $2 \mathrm{ER} \alpha$ antibodies is in general agreement for MCF-7, but not for the thyroid cancer cell lines (Fig. 2B and C). This is likely due to variability in ER $\alpha$ epitope detection between these antibodies. HC-20 also recognizes an $80-\mathrm{kDa}$ band which the manufacturer (Santa Cruz) terms non-specific, but which also corresponds to an ER $\alpha$ splice variant containing a duplication of exons 6 and 7 (47). However, the presence of this band in the baculovirus-expressed rhER $\alpha$ lane, suggests, in agreement with the manufacturer's web site, that this band is non-specific. Because FTC133 and TPC1 were non-responsive to $E_{2}$ in the cell proliferation assay (data not shown), these cell lines were excluded from further analyses.

To examine the expression of ERß in thyroid cancer cells, Western blots were performed with polyclonal ERß antibody $\mathrm{H} 150$ that recognizes the N-terminus of ERß, 


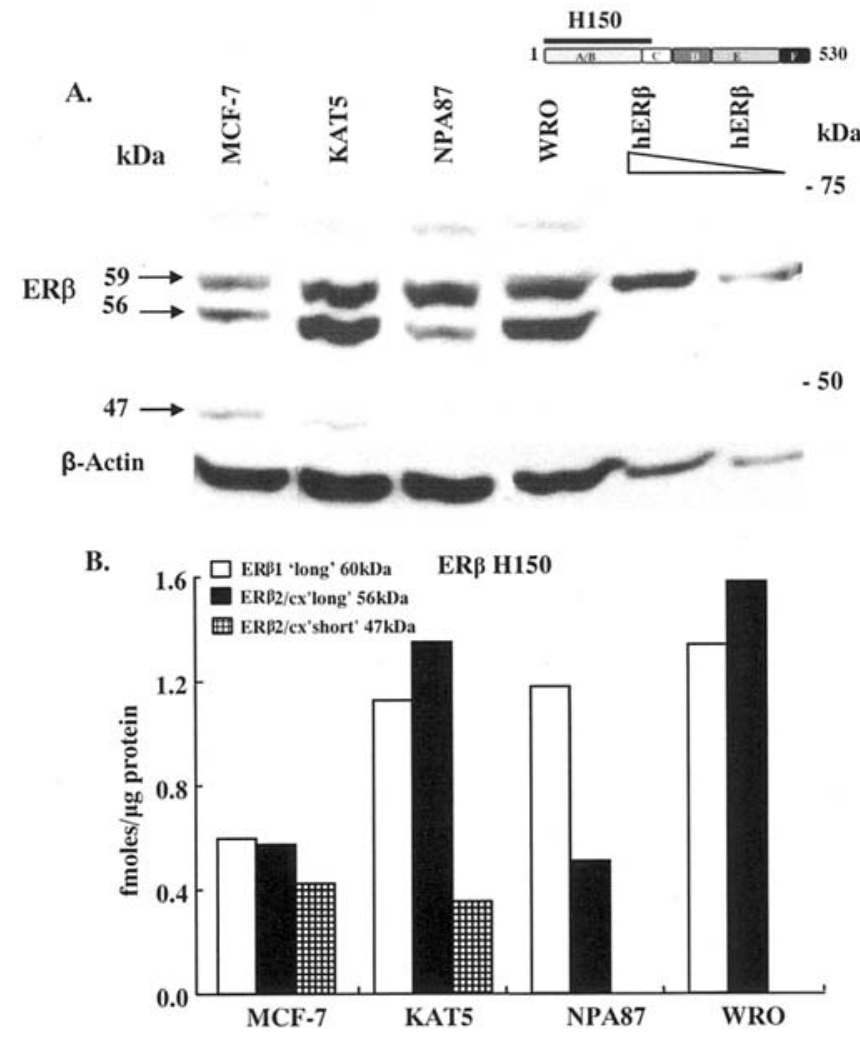

Figure 3. KAT5, NPA87, and WRO thyroid cancer cells express ERß. The expression of ERß was examined by immunoblotting using $40 \mu \mathrm{g}$ of WCE protein and using ERß polyclonal H150 antibody. H150 recognizes an epitope in the $\mathrm{N}$ terminus of ERß, as indicated by the black bar above the $\mathrm{A} / \mathrm{B}$ domain in the ERß diagram provided at the top right. One and a half fmoles of recombinant human (rh) ERß was included as a control, as indicated. The membrane was stripped and reprobed for $\beta$-actin. The migration of MW standards is indicated at the right $(\mathrm{kDa})$. The MW sizes for the immunoreactive bands, indicated at the left by arrows, were estimated as described in Materials and methods. The bar graph is a quantitation of the data in each blot. This is the result of a single experiment and is representative of at least three separate Western blots that show similar patterns of ERß expression.

(epitope indicated in Fig. 3). Full length ERß1 (59 kDa) and its apparent splice variants were identified in all 3 thyroid cancer cell lines and in MCF-7 cells (Fig. 3). The identity of the apparent ERß splice variants was inferred from their MW size (48). The full length ERß1 'long' isoform is the $59 \mathrm{kDa}$ band that was expressed in MCF-7 (positive control), KAT5, NPA87, and WRO cells and its identity was confirmed by identical migration of baculovirus-expressed rhERß (49) (Fig. 3). Notably, all three thyroid cancer cell lines express higher amounts of ERß1 than MCF-7 cells. More ERß2/cx 'long' form, $56 \mathrm{kDa}$, was seen in KAT5 and WRO cells compared to MCF-7 cells. The relative levels of the ERß1 were similar in all 3 thyroid cancer cell lines. The total expression of ERß2/cx 'long' was similar in KAT5 and WRO cells whereas ERß2/cx 'long' was only detected in KAT5 and MCF-7 cells. Based on calculations using known amounts of rhER $\alpha$ and rhERß, the protein expression of ERß was lower than ER $\alpha$ in these 3 thyroid cancer cell lines and MCF-7 cells (Figs. 2B and D, and 3B).

Intracellular localization of ER $\alpha$ and ER $\beta$. The cellular localization of ER $\alpha$ and ERß in the 3 thyroid cancer cell lines was examined by immunofluorescent staining with and without a 45-min treatment with $10 \mathrm{nM} \mathrm{E}$. Again, MCF-7 cells were used as a positive control. In untreated KAT5, NPA87, and WRO thyroid cancer cells, ER $\alpha$ and ERß were in the cytoplasm and enriched in the perinuclear regions and, as expected (50), in the cytoplasm of MCF-7 cells (Fig. 4A). The yellow in the merged images indicates an overlap in the localization of $\mathrm{ER} \alpha$ and ERß in all cell lines (Fig. 4A). Following 45 min of $\mathrm{E}_{2}$ treatment, ER $\alpha$ and ERß in KAT5, NPA87 and WRO cells remained in the cytoplasm. In contrast, both ER $\alpha$ and ERß were, as anticipated $(50,51)$, translocated to the nucleus in MCF-7 cells (Fig. 4B). Thus, ER $\alpha$ and ERß exhibit different cellular responses to $\mathrm{E}_{2}$ in thyroid cancer cells versus MCF-7 breast cancer cells. Specifically, $\mathrm{E}_{2}$ fails to stimulate the translocation of ER $\alpha$ and ER, to the nucleus in the 3 thyroid cancer cell lines.

Transcriptional ER activity in transiently transfected thyroid cancer cells. To examine the transcriptional activity of endogenous ER $\alpha$ and ERß in the thyroid cancer cells, each cell line was transiently transfected with a reporter plasmid containing two tandem copies of a consensus ERE $(33,52)$ and the ability of $\mathrm{E}_{2}$, ICI, 4-OHT, and RAL, to stimulate luciferase activity was examined. $\mathrm{E}_{2}$ had no effect on luciferase activity in KAT5, NPA87, and WRO cells (Fig. 5A). The same concentration of $\mathrm{E}_{2}$ elicited a 2-fold stimulation of luciferase activity in MCF-7 cells (Fig. 5A), indicating that the lack of response was not due to inactivity of the ERE-luciferase reporter. The thyroid cells were transfected since the Firefly and Renilla luciferase readings were $\sim 300,000$ and $\sim 90,000$ (data not shown). 4-OHT, ICI, and RAL had no significant effect on luciferase activity in KAT5, NPA87, and WRO cells (Fig. 5A). In contrast, both 4-OHT and ICI inhibited $\mathrm{E}_{2}$-induced luciferase activity in MCF-7 cells. These data indicate that although $\mathrm{ER} \alpha$ and ERß are present in KAT5, NPA87, and WRO thyroid cancer cells, they do not activate reporter gene transcription. These data are also in agreement with the lack of nuclear ER $\alpha$ and ERß in these 3 cell lines (Fig. 4).

Two possible explanations for the lack of reporter gene activity in the thyroid cancer cells are: i) the lack of nuclear $\mathrm{ER} \alpha$ and ERß (Fig. 4B); or ii) inactivity of the expressed ERs. Thus, we examined the effect of transient transfection of $\mathrm{ER} \alpha$ and $\mathrm{ER} \beta$ on ERE-driven luciferase activity in each cell line (Fig. 5B). $\mathrm{E}_{2}$-induced transcriptional response in ER $\alpha$ and ERß-transfected KAT5 and WRO cells (Fig. 5B). Basal reporter activity was increased in NPA87 transfected with $\mathrm{ER} \alpha$ and no further induction was detected with $\mathrm{E}_{2}$ treatment (Fig. 5B). Transfection with ERß increased $\mathrm{E}_{2^{-}}$ induced luciferase activity in NPA87 cells. As expected, transfection of $\mathrm{ER} \alpha$ and $\mathrm{ER} \beta$ increased $\mathrm{E}_{2}$-induced luciferase activity in MCF-7 cells (Fig. 5B). Thus, the lack of ERE-driven luciferase activity in the thyroid cancer cells (Fig. 5A) may be due to low ER $\alpha$ expression (Fig. 2) or the presence of dominant negative ER $\alpha$ splice variants that may inhibit endogenous ER transcriptional activity on the transfected ERE-reporter (42).

MTA1 expression in thyroid cancer cells. MTA1 is a corepressor of ER $\alpha$-driven gene transcription in breast cancer (17), and its short form variant, MTA1s, interacts with ER $\alpha$ and 
A. Vehicle (EtOH)

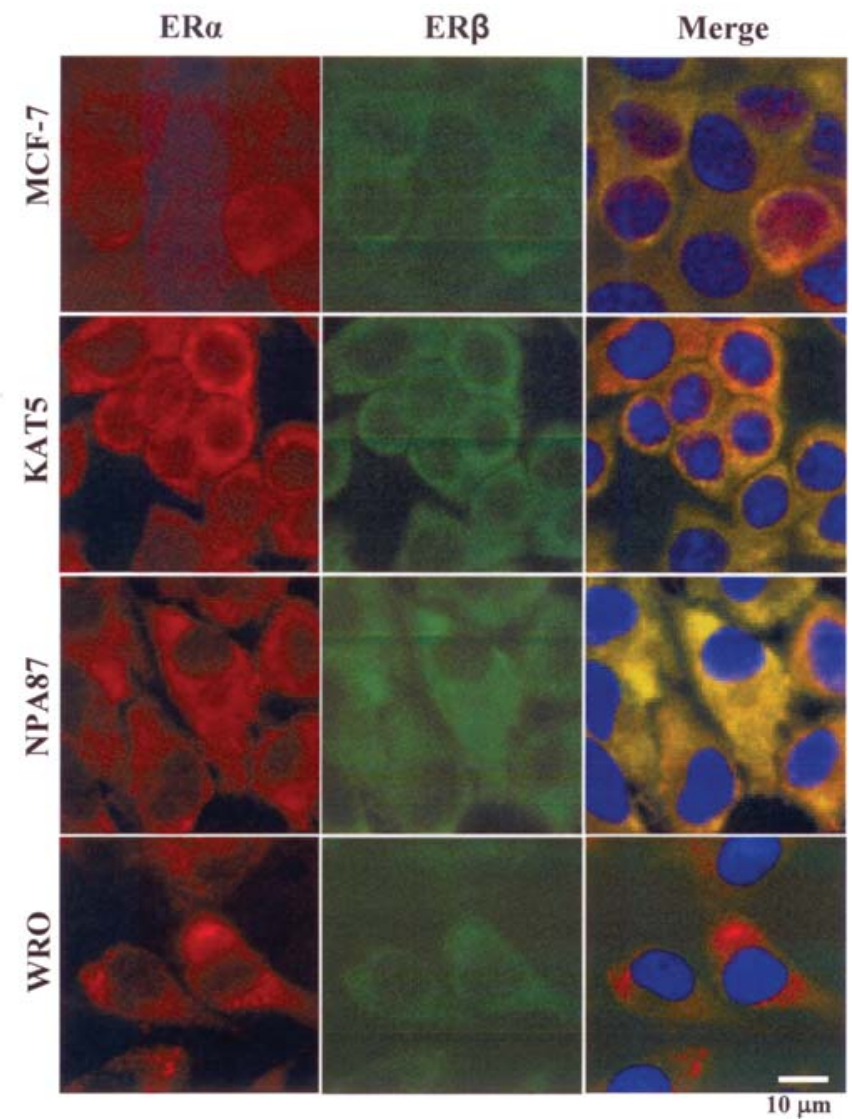

B. $10 \mathrm{nM} \mathrm{E}_{2}, 45 \mathrm{~min}$

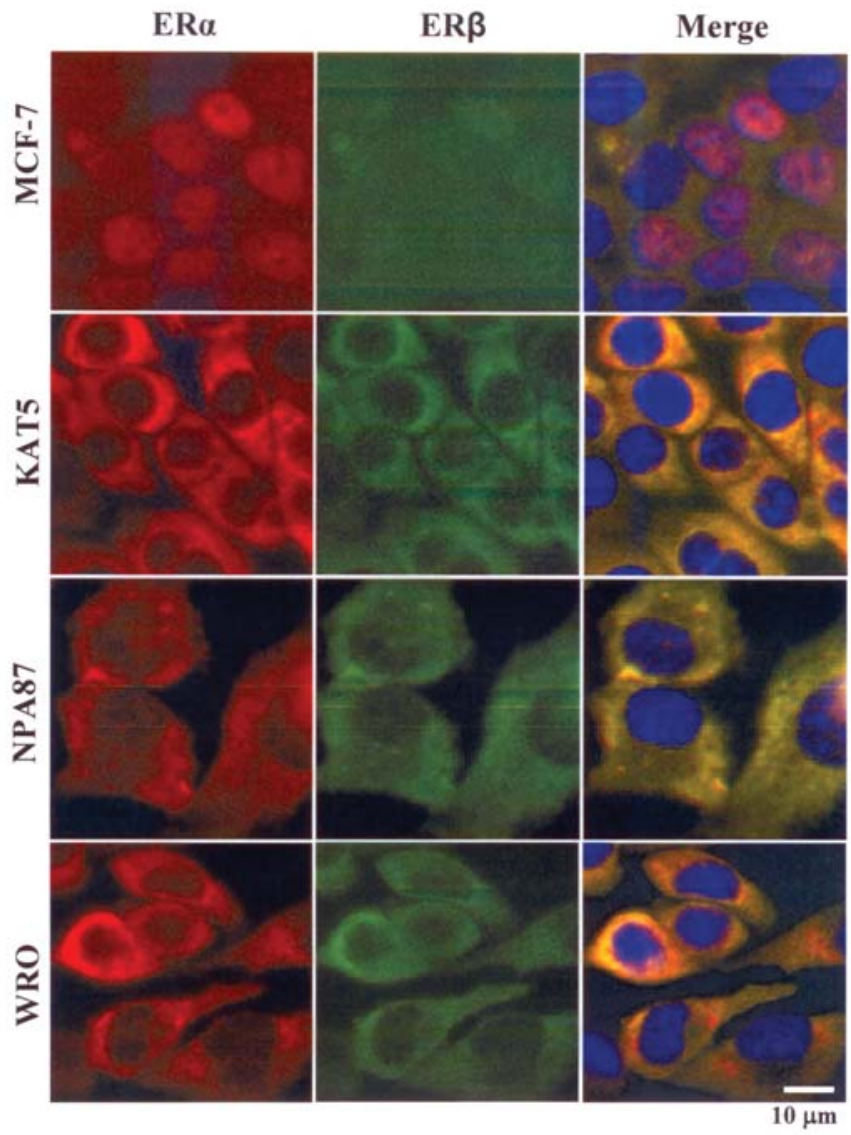

Figure 4. Cellular localization of ER $\alpha$ and ERß. MCF-7 human breast cancer cells (as a positive control) or the indicated thyroid cancer cell lines were treated with vehicle [EtOH (A) or $10 \mathrm{nM} \mathrm{E}_{2}$ for $45 \mathrm{~min}(\mathrm{~B})$ and immunostained for ER $\alpha$ (red) and ERß (green) using an anti-ER $\alpha$ (AER320) and anti-ERß (H150) antibodies as described in Materials and methods]. Cell nuclei were counterstained with DAPI. Merged images are shown in the third column. Images were captured using Olympus iX50 inverted fluorescence microscope as described in Materials and methods. Scale bar, $10 \mu \mathrm{m}$.

sequesters ER $\alpha$ in the cytoplasm, thus inhibiting transcriptional activity (18). We tested the hypothesis that the lack of endogenous ER transcriptional activity in the thyroid cancer cell lines is due to higher MTA1s expression in the thyroid cancer cell lines compared in MCF-7. Western blotting revealed that all three thyroid cancer cell lines express levels of MTA1 comparable to MCF-7 cells (data not shown). We used three different antibodies in an attempt to identify MTA1s (54 kDa) in these cells, but did not detect this variant (data not shown). Thus, we conclude that higher MTA1s is not the reason for the lack of endogenous genomic ER activity in these three thyroid cancer cell lines.

Effect of $E_{2}$ on endogenous estrogen responsive gene transcription. To further address the activity of endogenous ER in thyroid cancer cells, we examined whether $\mathrm{E}_{2}$ increases mRNA expression of PR, cathepsin D, and cyclin D1, well-established estrogen target genes (53), in the 3 thyroid cancer cell lines and again, MCF-7 cells served as a positive control for $\mathrm{E}_{2}$ responses. Real-time quantitative PCR (Q-RT-PCR) showed that PR was increased 19-fold in response to $E_{2}$ in MCF-7 cells (Fig. 6 inset). In contrast, PR mRNA was undetectable in KAT5, NPA87, and WRO cells even after $\mathrm{E}_{2}$ treatment
(Fig. 6 inset). These data agree with a previous report that PR was not detected in normal thyroid or in thyroid carcinomas by enzyme immunoassay (11). We conclude that PR is not an endogenous ER target gene in KAT5, NPA87, and WRO thyroid cancer cells.

Cathepsin D is a lysosomal protease involved in proteolytic degradation, cell invasion, and apoptosis (54) which is highly expressed in thyroid carcinomas as compared to normal thyroid gland $(11,54,55)$. Cathepsin D expression is stimulated by $E_{2}$ in breast cancer cells $(54,55)$. As expected, $E_{2}$ increased cathepsin D (CTSD) mRNA expression in MCF-7 cells in an ER-dependent manner since ICI inhibited $\mathrm{E}_{2}$-induced CTSD expression (Fig. 6). Basal CTSD expression was higher in NPA87 and WRO than MCF-7 and KAT5 cells (data not shown). KAT5 had the lowest CTSD expression (data not shown). $\mathrm{E}_{2}$ increased CTSD expression in WRO cells and this was blocked by ICI (Fig. 6). We thus conclude that CTSD gene transcription is not $\mathrm{E}_{2}$-regulated in KAT5 or NPA87 cells, whereas $\mathrm{E}_{2}$ increased CTSD transcription in WRO cells by an ER-dependent mechanism.

Cyclin D1 expression in $E_{2}$ treated thyroid cancer cells. Cyclin D1 is a major regulator of the $G_{1}-S$ transition of the 
A.
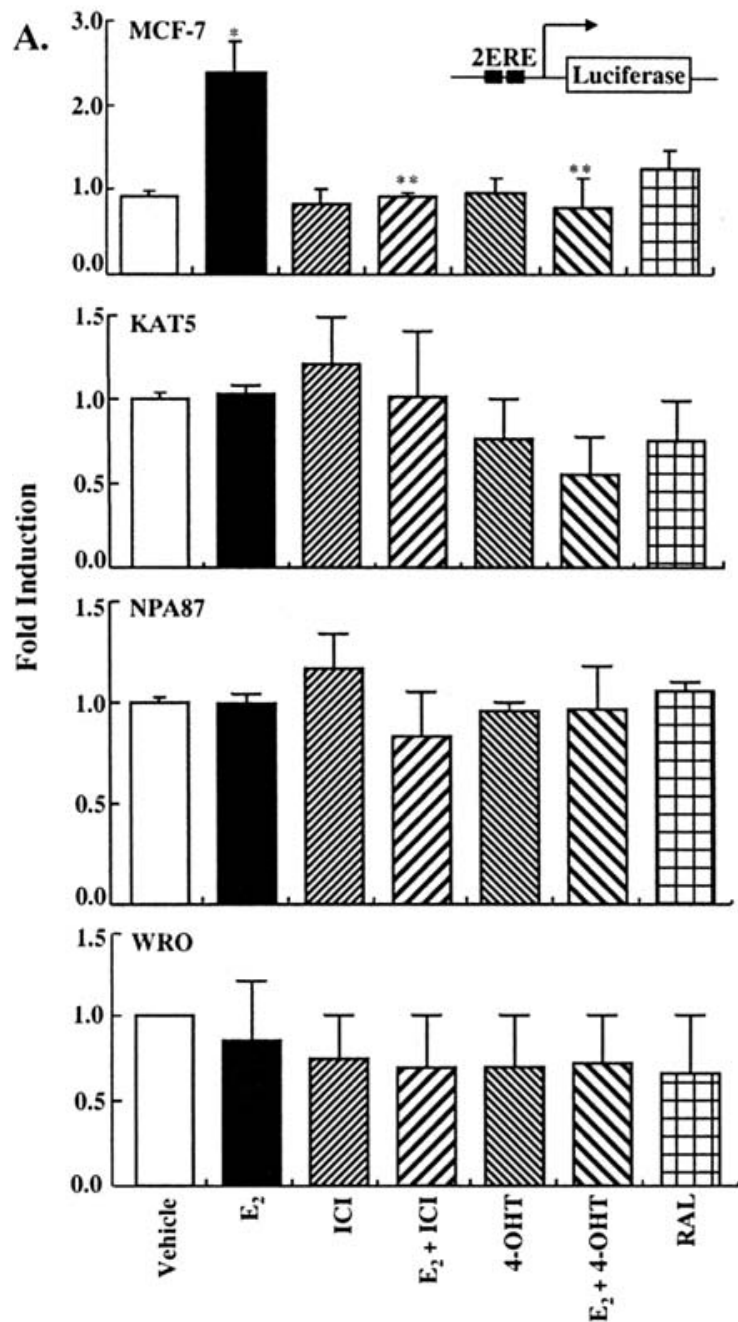
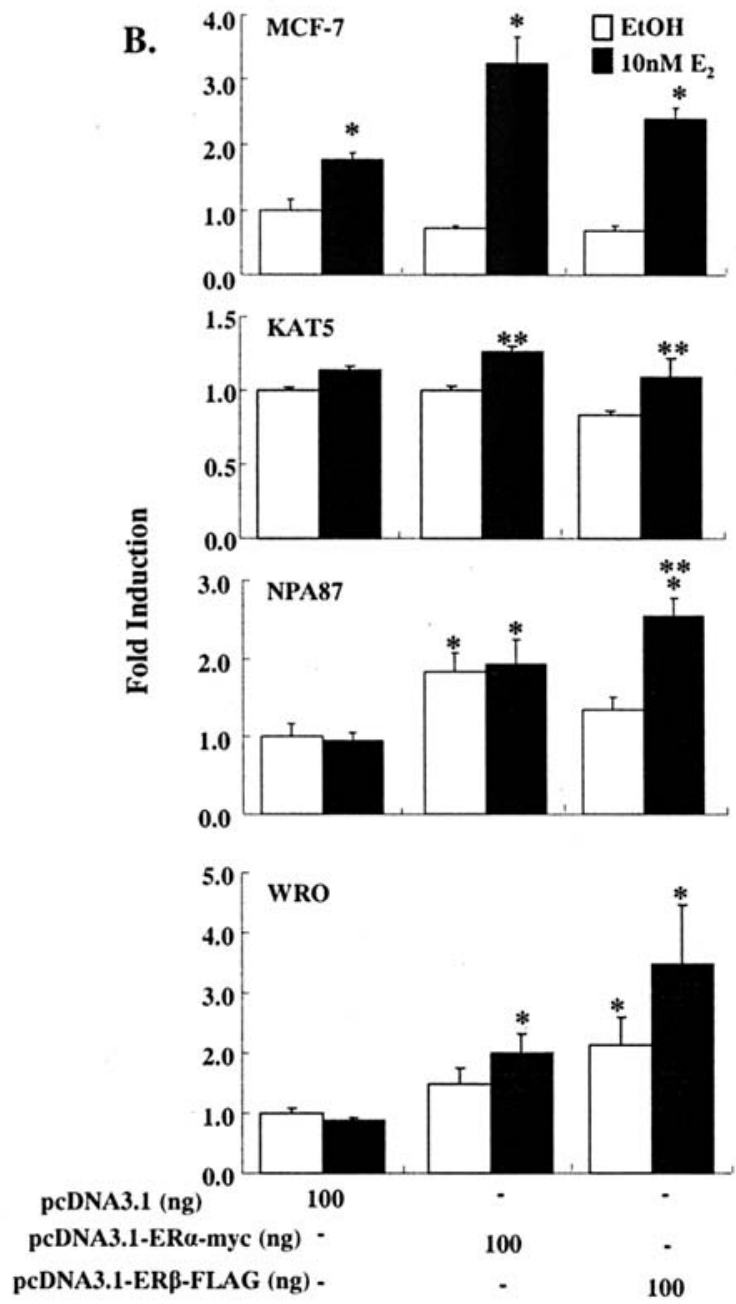

Figure 5. ER transcriptional activity in thyroid cancer cells. (A) MCF-7 breast, or KAT5, NPA87, and WRO thyroid cancer cells were transiently transfected with pGL3-pro-2EREc38 luciferase and a Renilla reporter for a dual luciferase reporter assay as described in Materials and methods. Twenty-four hours posttransfection, the cells were treated with $10 \mathrm{nM} \mathrm{E}$, $100 \mathrm{nM} \mathrm{ICI}, 100 \mathrm{nM}$ 4-OHT, $10 \mathrm{nM}$ RAL, $10 \mathrm{nM}$ DPN, and $10 \mathrm{nM}$ PPT for $24 \mathrm{~h}$. (B) MCF-7 breast, or KAT5, NPA87, and WRO thyroid cancer cells were transiently transfected with pGL3-pro-2EREc38 luciferase and a Renilla reporter for a dual luciferase reporter assay as described in Materials and methods. In addition, the cells were transfected with an empty expression vector (pcDNA3.1), or with the ER $\alpha$ or ERß expression plasmids, as indicated. The transfected cells were treated with EtOH or $10 \mathrm{nM} \mathrm{E}_{2}$ for $30 \mathrm{~h}$. For (A and B), the luciferase response was normalized to vehicle (EtOH/DMSO). Values are the mean \pm SEM of 3 independent experiments. *Significantly different compared to vehicle (EtOH) $(\mathrm{p}<0.05) .{ }^{* *}$ Significantly different from the $\mathrm{E}_{2}$ value $(\mathrm{MCF}-7$ data in $\mathrm{A})$.

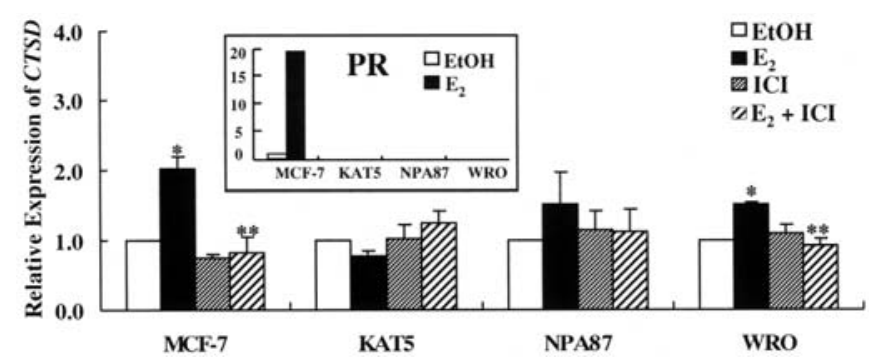

Figure 6. Endogenous $\mathrm{E}_{2}$ target gene transcription in thyroid cancer cells. MCF-7 or the indicated thyroid cancer cells were treated with vehicle (EtOH), $10 \mathrm{nM} \mathrm{E}$, $100 \mathrm{nM}$ ICI, or the combination for $6 \mathrm{~h}$. Q-RT-PCR analysis of PR (inset) and cathepsin D (CTSD) were normalized to $18 \mathrm{~S}$ and the fold comparison was against MCF-7 treated with EtOH as described in Materials and methods. $\mathrm{E}_{2}$ did not induce PR in any of the thyroid cancer cell lines and induced cathepsin D only in WRO cells. Values are the mean \pm SEM of 3 independent experiments. *Significantly different from the EtOH value $(\mathrm{P}<0.05) .{ }^{* *}$ Significantly different from the $\mathrm{E}_{2}$ alone value in that cell line $(\mathrm{P}<0.05)$. cell cycle (56). $\mathrm{E}_{2}$ induces cyclin D1 (CCND1) transcription (57). We examined the effect of $\mathrm{E}_{2}$ and ICI on CCNDI expression in the 3 thyroid cancer cell lines and MCF-7, as a positive control, at various times (Fig. 7). As expected, $\mathrm{E}_{2}$ stimulated $C C N D 1$ transcription at $1 \mathrm{~h}$ in MCF-7 and ICI blocked the $\mathrm{E}_{2}$-induced $C C N D 1$ expression, indicating ER-dependence (Fig. 7A). In KAT5, $\mathrm{E}_{2}$ increased CCNDI expression at $1 \mathrm{~h}$ and ICI blocked $\mathrm{E}_{2}$-induced CCND1, indicating ER-dependence (Fig. 7B). ICI stimulated CCNDI transcription at the $9 \mathrm{~h}$ time-point in KAT5 and $\mathrm{E}_{2}$ reduced this stimulation, suggesting an ER-mediated response. In NPA87, basal CCND1 transcription was reduced at 1,3 and $9 \mathrm{~h}$ with EtOH (vehicle) treatment. The potential mechanism for this effect of EtOH was not evaluated and we compared the effects of the ER ligands relative to the basal CCND1 transcript level with EtOH treatment at each time-point. $\mathrm{E}_{2}$ increased $C C N D 1$ transcription at 1 and $9 \mathrm{~h}$. ICI alone had no 

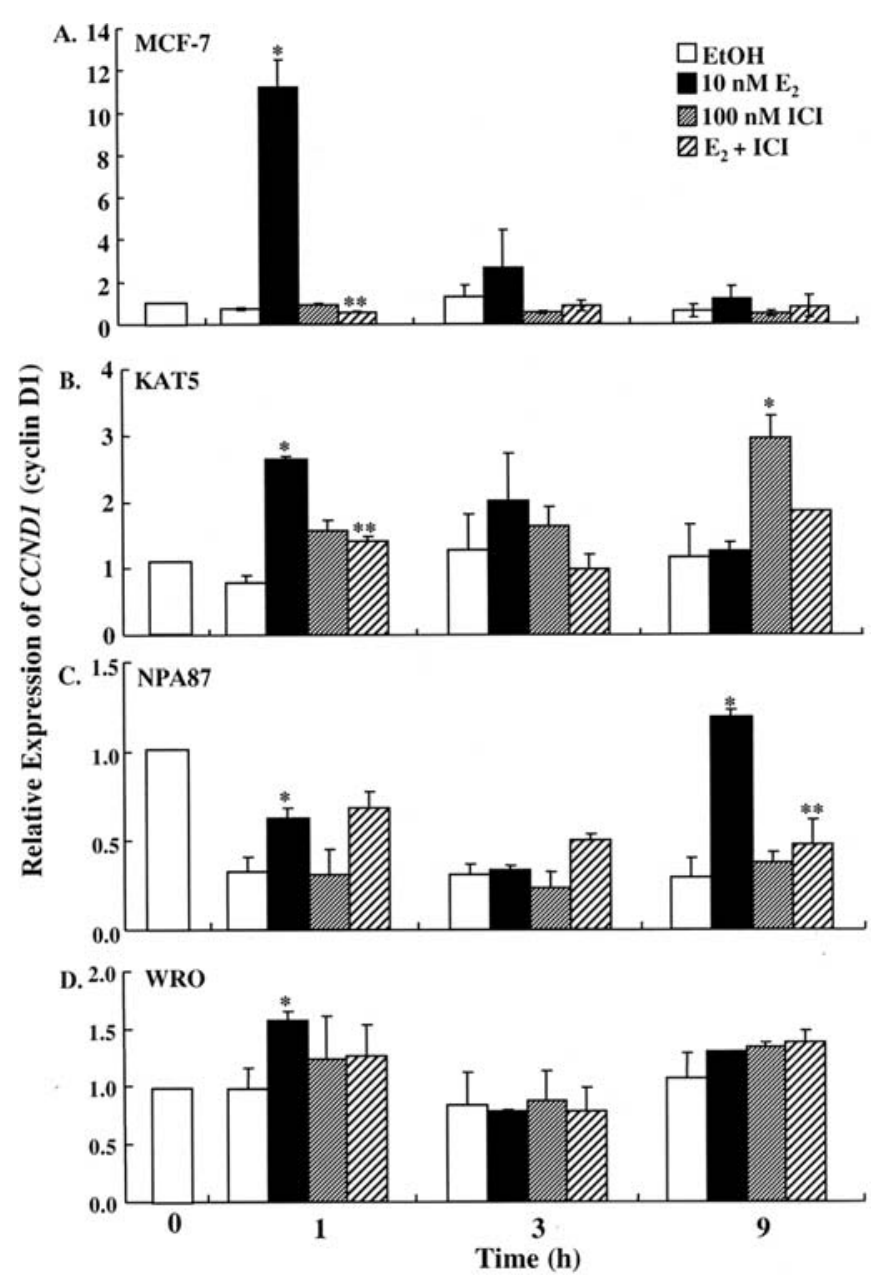

Figure 7. $\mathrm{E}_{2}$ induces cyclin $\mathrm{D} 1$ (CCND1) transcription in thyroid cancer cells. MCF-7 (A) or the indicated thyroid cancer cells (B-D) were treated with vehicle $(\mathrm{EtOH}), 10 \mathrm{nM} \mathrm{E} \mathrm{E}_{2}, 100 \mathrm{nM}$ ICI, or the combination for the indicated time. Q-PCR analysis of CCND1 was normalized to $18 \mathrm{~S}$ and the fold comparison was against EtOH time zero for each cell line as described in Materials and methods. Values are the average \pm SEM of three separate experiments. *Significantly different $(\mathrm{P}<0.05)$ from the EtOH value at that time. ${ }^{* *}$ Significantly different from the $10 \mathrm{nM} \mathrm{E}_{2}$ value at that time. Differences were examined within each cell line.

effect on $C C N D 1$ transcription. ICI did not block $\mathrm{E}_{2}$-induced $C C N D 1$ at $1 \mathrm{~h}$ but blocked $\mathrm{E}_{2}$ induced $C C N D 1$ at $9 \mathrm{~h}$ (Fig. 7C). In WRO, $\mathrm{E}_{2}$ increased $C C N D 1$ transcription, but this was not abrogated by ICI (Fig. 8D). Overall, we conclude that $\mathrm{E}_{2}$ regulates CCND1 transcription in KAT5, NPA87, and WRO cells with different cell-line-specific kinetics by classical, genomic ER.

Knockdown of ERa or ERß reduces $E_{2}$-upregulated CCNDI and CTSD transcription in KAT5 and WRO cells. KAT5 and WRO were selected as representative papillary and follicular thyroid cancer cells for ER knockdown studies. To determine the involvement of ER $\alpha$ and ERß in the $E_{2}$ induction of cyclin D1 in KAT5 and WRO cells and cathepsin D in WRO (Fig. 7), ER $\alpha$ and ERß were specifically knocked-down using siRNA. Because of the potential effects of EtOH on basal CCND1 transcription in NPA87 (Fig. 7C), further experiments were not pursued in this cell line. Experiments to optimize $\mathrm{ER} \alpha$ and ER $\beta$ knockdown revealed that $100 \mathrm{nM}$ siRNA was the most effective concentration to silence the expression of either ER subtype without affecting cell viability (data not shown). siER $\alpha$ reduced ER $\alpha$ mRNA by $75 \%$ in KAT5 cells with no effect on ERß (Fig. 8A) and ER $\alpha$ protein was reduced $\sim 55 \%$, likewise with no effect on ERß protein (Fig. 8B). siER 3 reduced ERß mRNA by $83 \%$ in KAT5 cells, but ER $\alpha$ mRNA was reduced $\sim 50 \%$ as well (Fig. 8 A). ERß protein was reduced $\sim 60 \%$ with siERß in KAT5 cells and a $<10 \%$ change in ER $\alpha$ protein was detected (Fig. 8B). siER $\alpha$ reduced $\mathrm{ER} \alpha$ mRNA by $65 \%$ in WRO cells with an $\sim 15 \%$ reduction in ERß mRNA (Fig. 8C) and ER $\alpha$ protein was reduced $\sim 60 \%$ with $50 \%$ increase in ERß protein level (Fig. 8D). siER $\beta$ reduced ER $\beta$ mRNA by $50 \%$ in WRO cells and ER $\alpha$ was increased by $\sim 40 \%$ in these cells (Fig. 8C). In WRO cells, siERß reduced ERß protein by $60 \%$, but, in contrast to the increase in ER $\alpha$ mRNA, no change in $\mathrm{ER} \alpha$ protein was detected (Fig. 8D).

As seen in Fig. 8E, $\mathrm{E}_{2}$ induced $C C N D 1$ in KAT5 cells transfected with the siControl and this induction was ablated by ICI. Knockdown of ER $\alpha$ resulted in elevated basal levels of CCND1 in KAT5 cells. However, siER $\alpha$ blocked further induction of $C C N D 1$ transcription by $\mathrm{E}_{2}$, thus reducing $C C N D 1$ relative to basal. In contrast, knockdown of ERß in KAT5 cells did not alter basal CCND1 expression, but inhibited $\mathrm{E}_{2}$-induced $C C N D 1$ transcription. ICI reduced basal CCNDI in the cells in which ERß was reduced with siERß (Fig. 8E). These data suggest that basal expression of $C C N D 1$ is regulated by $\mathrm{ER} \alpha$ whereas $\mathrm{E}_{2}$-induced expression of $C C N D 1$ in KAT5 cells is controlled by both ER $\alpha$ and ERß. Further, the knockdown of ERß 'unmasks' the ability of ICI-occupied ER $\alpha$ to inhibit basal $C C N D 1$ transcription. In WRO cells, $\mathrm{ER} \alpha$ knockdown blocked $\mathrm{E}_{2}$-induced CTSD transcription (Fig. 8F) As seen for KAT5, siER $\alpha$ resulted in elevated basal CCND1 in WRO cells (Fig. 8G). Likewise, ER $\alpha$ knockdown abrogated the $\mathrm{E}_{2}$-induced increased expression of $C C N D 1$ but, in contrast to KAT5, ERß knockdown did not inhibit $\mathrm{E}_{2}$-induced $C C N D 1$ expression (Fig. 8G). Together these data indicate a role for $\mathrm{ER} \alpha$ in the $\mathrm{E}_{2}$ increased expression of $C C N D 1$ in both KAT5 and $\mathrm{WRO}$ and a role for ERß in $\mathrm{E}_{2}$-regulation of this gene in KAT5.

Knockdown of ERa or ER, inhibits $E_{2}$-induced ERK1/2 phosphorylation in KAT5 and WRO cells. Having established that non-genomic $\mathrm{E}_{2}$ signaling through $\mathrm{MEK}$ and PI3K play a role in $\mathrm{E}_{2}$-induced cell proliferation (Fig. 1) and that knockdown of either ER $\alpha$ or ERß abrogates the $E_{2}$-induced cyclin D1 (CCND1) transcription in both KAT5 and WRO cells (Fig. 8E and $\mathrm{G}$ ), we evaluated the impact of ER subtype-specific knockdown on $\mathrm{E}_{2}$-induced non-genomic signaling by examining ERK1/2 phosphorylation (p-ERK). Previous investigators reported that KAT5 cells required at least $1 \mathrm{~h} \mathrm{E}$ treatment to increase p-ERK (27). Hence, $1 \mathrm{~h} \mathrm{E}_{2}$ was the time selected for our knockdown experiments. $\mathrm{E}_{2}$ increased p-ERK/total ERK in both KAT5 and WRO cells and this increase was blocked by ICI and abrogated by knockdown of ER $\alpha$ or ERß, indicating ER-mediated ERK activation (Fig. 9). In WRO cells, the knockdown of ER $\alpha$ increased basal p-ERK compared to vehicle control, indicating a potential role for $\mathrm{ER} \alpha$ in regulating 
A.

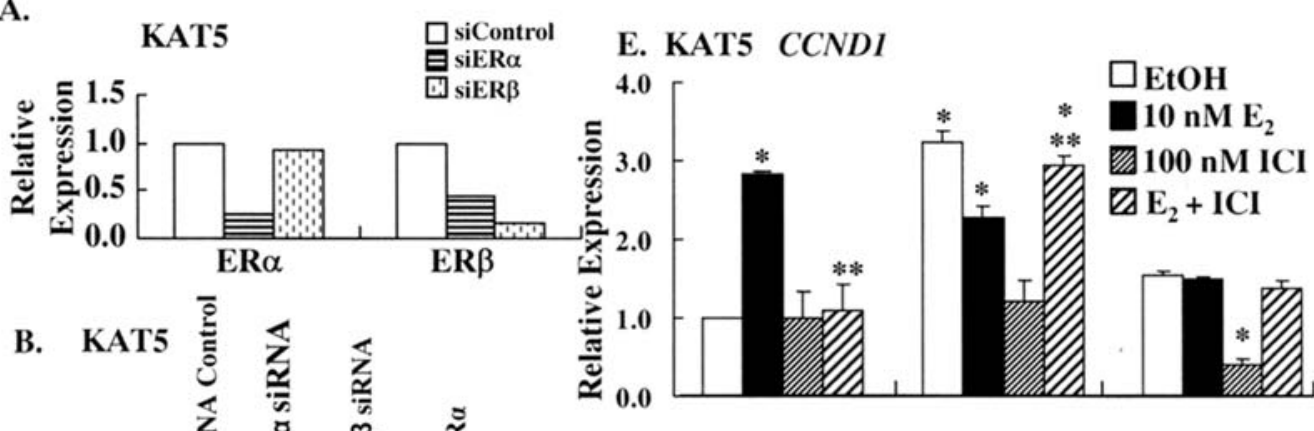

F. WRO CTSD

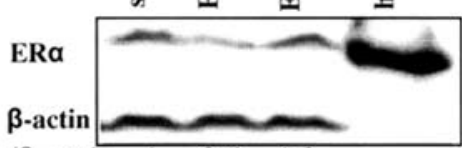

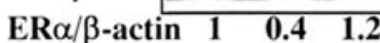

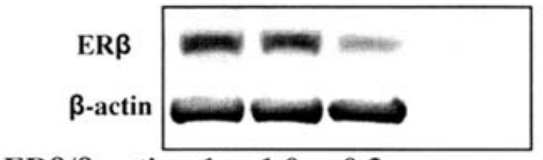

$\begin{array}{llll}E R / \beta \text {-actin } & 1 & 1.0 & 0.3\end{array}$
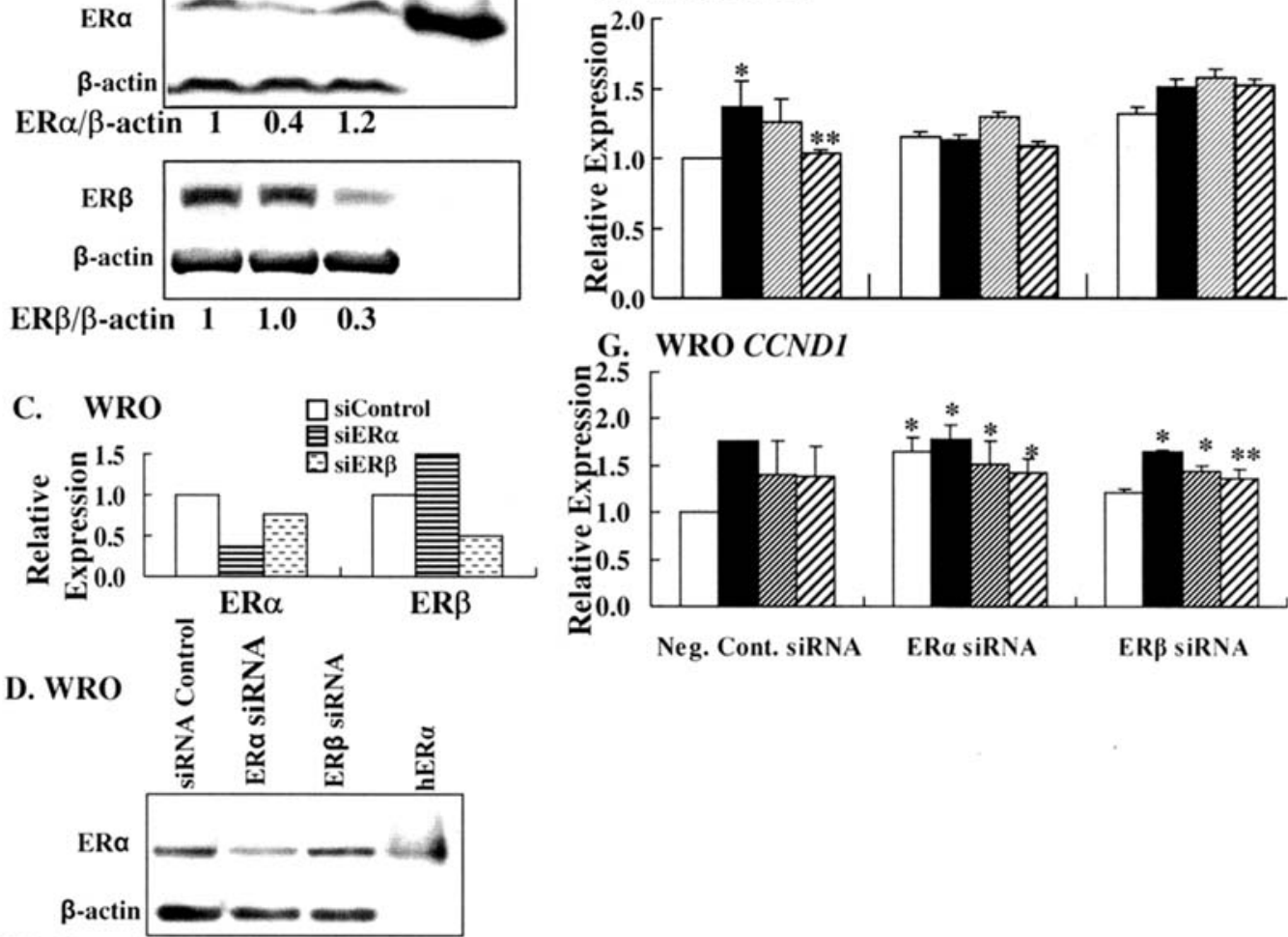

G. WRO CCNDI

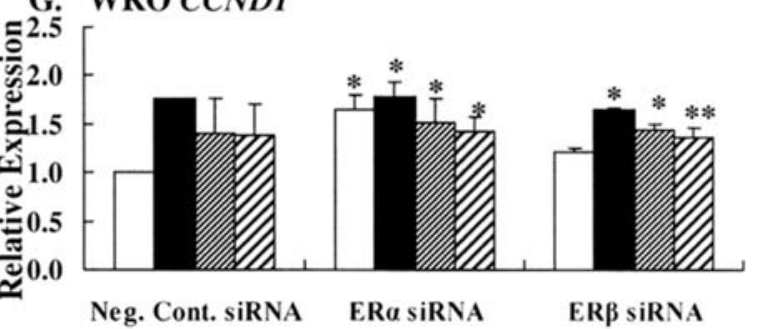

$\begin{array}{llll}E R \alpha / \beta \text {-actin } & 1 & 0.4 & 1.2\end{array}$

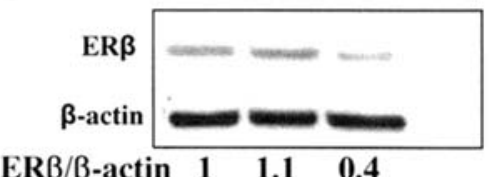

Figure 8. Knockdown of ER $\alpha$ and ERß in KAT5 and WRO cells reduces endogenous $\mathrm{E}_{2}$-target gene transcription. Transfection of KAT5 (A-B) and WRO (C-D) with siRNA against ER $\alpha$ and ERß selectively reduced ER subtype-specific mRNA expression $48 \mathrm{~h}$ after transfection and protein levels $72 \mathrm{~h}$ after transfection. Q-PCR and Western blots were performed and analyzed as described in Materials and methods. ESR1 and ESR2 mRNA values were normalized to $18 \mathrm{~S}$ and the fold comparison was against siRNA negative control as described in Materials and methods. Quantification of the ER protein bands was performed as described in Materials and methods and presented relative to B-actin with siRNA-transfected control set to 1. (E-F) Effect of knockdown of ER on ER target gene transcription. Cells were treated with $10 \mathrm{nM} \mathrm{E} \mathrm{E}_{2}$ or $100 \mathrm{nM} \mathrm{ICI}$ for $1 \mathrm{~h}$ for CCND1 (E and G) and $6 \mathrm{~h}$ for CTSD (F). The expression of CCND1 (E and G) and CTSD (F) was determined by Q-PCR, normalized to 18S, and the fold comparison was against EtOH as described in Materials and methods. Values are the average \pm SEM of three separate experiments. ${ }^{*}$ Significantly different from EtOH $(\mathrm{P}<0.05)$. ${ }^{* *}$ Significantly different from the $\mathrm{E}_{2}$ alone value for that gene in that cell line $(\mathrm{P}<0.05)$.

basal ERK activity. Together, these data indicate roles for $\mathrm{ER} \alpha$ and ERß in mediating $\mathrm{E}_{2}$-induced ERK1/2 phosphorylation in KAT5 and WRO thyroid cancer cells.

GPR30 expression is low in KAT5 and NPA87 papillary carcinoma cells. GPR30 was identified as a novel membrane estrogen receptor in 2000 (58). $E_{2}$ was reported to increase
WRO proliferation by activating GPR30 (22). No one has evaluated GPR30 expression in KAT5 or NPA87 thyroid cancer cells. We examined mRNA levels of GPR30 in the 3 thyroid cancer cell lines (Fig. 10). GPR30 expression was higher in WRO follicular than either KAT5 or NPA87 papillary thyroid carcinoma cells. MCF-7 cells had higher GPR30 than WRO cells. Because of the low or absent expression of 

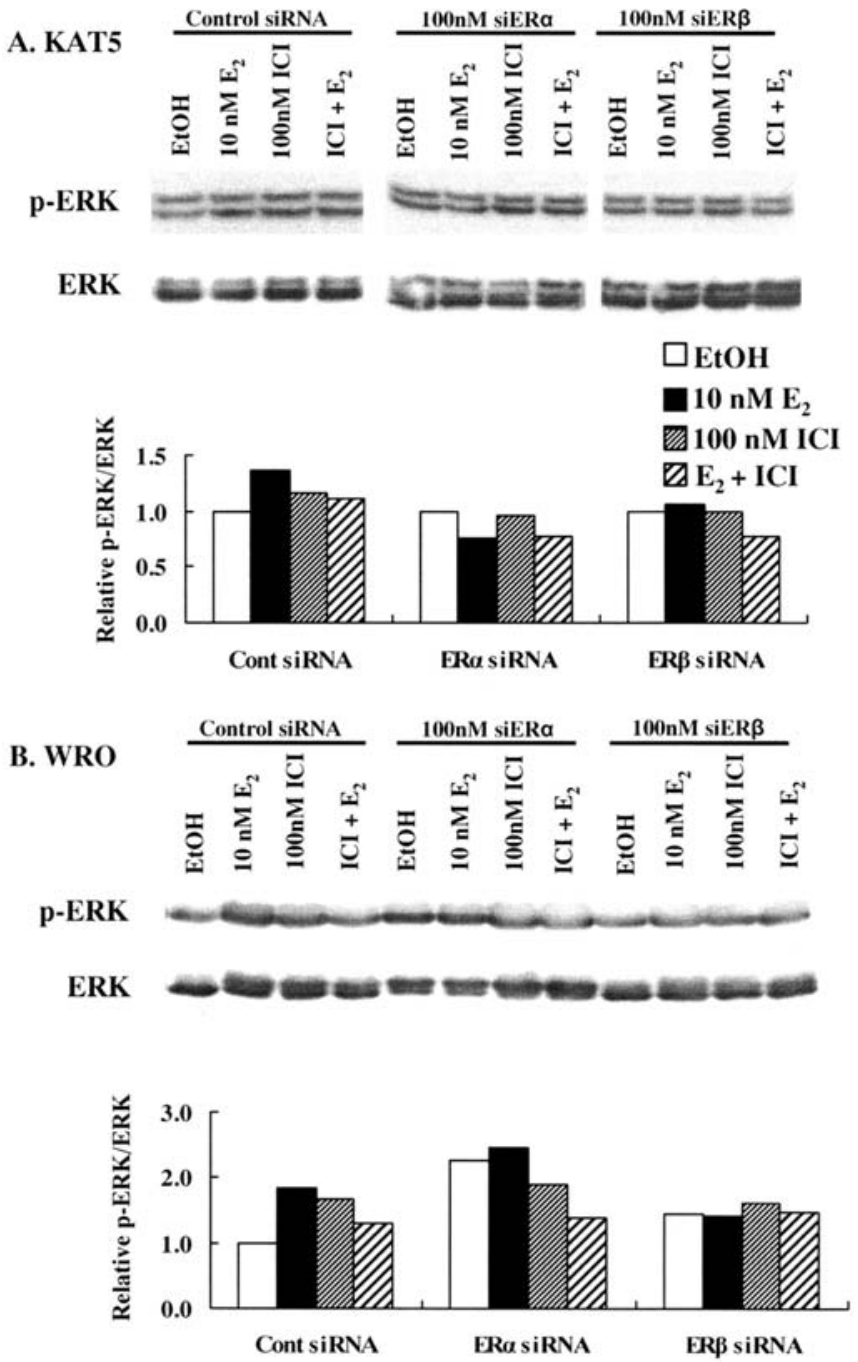

Figure 9. $\mathrm{E}_{2}$-induced ERK phosphorylation in thyroid cancer cell lines. KAT5 (A) and WRO (B) cells that had been transfected with control siRNA or siER $\alpha$ or siERß for $48 \mathrm{~h}$ were treated with $10 \mathrm{nM} \mathrm{E}_{2}$ or $100 \mathrm{nM}$ ICI for $1 \mathrm{~h}$. WCE were analyzed for ERK phosphorylation (p-ERK) and the blots were stripped and reprobed for total ERK (ERK). Densitometric values for p-ERK were normalized to ERK and control vehicle was set to 1 .

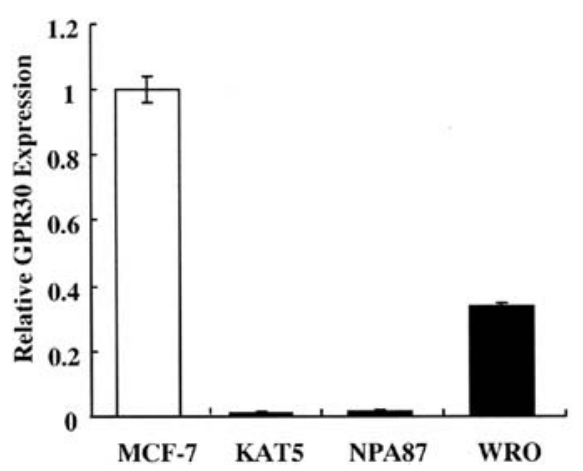

Figure 10. GPR30 expression is lower in thyroid cancer cells than MCF-7 cells. Q-PCR was performed using ABI TaqMan primer/probes on untreated cells. The $\mathrm{Ct}$ values were normalized to $18 \mathrm{~S}$ and normalized to $\mathrm{MCF}-7$. Values are the average of 3 determinations \pm SEM.

GPR30 mRNA in the three thyroid cancer cell lines, further studies were not pursued.

\section{Discussion}

Although thyroid cancer is predominantly a disease affecting premenopausal women, relatively few studies have examined the roles of $\mathrm{E}_{2}$ and $\mathrm{ER}$ in thyroid cancer cell proliferation $(4,22,27,28,59,60)$. Previous studies reported that $\mathrm{E}_{2}$ stimulated cell proliferation in FRTL5, a mouse thyroid cell line (61), FRO and WRO human follicular thyroid carcinoma cells (22), TT medullary thyroid carcinoma cells (62), papillary KAT5 cells $(27,59,60)$ and HTC-TSHr thyroid carcinoma cells (9). Despite these reports, the mechanisms involving $\mathrm{E}_{2}$-induced cell proliferation in these thyroid cancer cell lines are not clearly understood. Here we demonstrated that KAT5, NPA87, and WRO thyroid cancer cell lines responded proliferatively to $\mathrm{E}_{2}$ and that ICI 182,780 (Fulvestrant) blocked $\mathrm{E}_{2}$-induced proliferation, indicating that the $\mathrm{E}_{2}$-response was ER mediated. The $\mathrm{E}_{2}$-induced proliferation in KAT5 is similar to that reported previously $(27,59,60)$. In contrast, we found that follicular FTC133 and papillary TPC1 thyroid cancer cells were not responsive to $\mathrm{E}_{2}$ (data not shown), despite expressing $\mathrm{ER} \alpha$. These data conflict with a report that $\mathrm{E}_{2}$ stimulated FTC133 cell proliferation as determined by cell counting (63). The reason for this disparity is unknown, but differences in cell maintenance and assay conditions are likely involved. Our studies using ER subtype-selective agonists and antagonists (Fig. 1) indicate that $E R \alpha$ is responsible for the $E_{2}$-induced proliferation in KAT5 and WRO cells whereas ERß appears to play a role in both NPA87 and WRO cells. In contrast to a previous report (64), we observed that 4-OHT stimulated KAT5 and WRO proliferation, but had no significant effect on NPA87. Notably, we used $100 \mathrm{nM} 4-\mathrm{OHT}$ and the previous reports used higher concentration, i.e., $1.5 \mu \mathrm{M}$ tamoxifen $(64,65)$. Our WRO data consistent with another report demonstrating that 4-OHT increased cell proliferation in WRO through GPR30 (22) since we detected GPR30 mRNA only in WRO and not in KAT5 or NPA87 cells. Here we observed that RAL stimulated WRO, but not KAT5 or NPA87 cell proliferation and we again speculate a role for GPR30 in this response. Both 4-OHT or RAL inhibited $\mathrm{E}_{2}$-induced proliferation of WRO and NPA87, but RAL did not inhibit $\mathrm{E}_{2}$-activated proliferation of KAT5. These data reflect the established cellspecificity of SERM pharmacology, i.e., 4-OHT and RAL are ER agonists in some cells and antagonists in others (66).

We demonstrated that KAT5, NPA87, and WRO thyroid cancer cells express full length ER $\alpha$ and ERß, as well as a number of previously reported (14), subtype-specific splice variants. Our data are in agreement with a previous report that ER $\alpha 46$ and ER, $59 \mathrm{kDa}$ are expressed in WRO cells (22) and that KAT5 cells have full length $\operatorname{ER} \alpha(27,59,60)$. The 36 and $58 \mathrm{kDa} \mathrm{ER} \alpha$ protein splice variants have not been reported in the thyroid cancer cells and their roles remain to be resolved. Because higher ER $\alpha 46$ expression was seen compared to the full length ER $\alpha$ in each of the three thyroid cancer lines used in this study (Fig. 2A), it is possible that dominant negative activity of ER $\alpha 46$, reported in breast cancer cells $(67,68)$, and ER $\alpha 36$, also reported in breast cancer cell lines and transfected HEK-293 cells $(45,46)$, and may inhibit genomic ER signaling in thyroid cancer cells, thus offering an explanation for our transient transfection and Q-PCR data. 
Further studies will be required to dissect the role of ER $\alpha$ splice variants in $\mathrm{E}_{2}$ responses in thyroid cancer cells.

The classical estrogen signaling paradigm involves activation of ER by binding of $\mathrm{E}_{2}$ leading to ER hetero- or homodimerization, translocation to the cell nucleus, interaction with DNA and coregulators leading to alteration in gene transcription that stimulates cell cycle progression $(52,69)$. To our surprise, despite the fact that KAT5, NPA87, and WRO express full length $\mathrm{ER} \alpha$ and $\mathrm{ER} \beta, \mathrm{E}_{2}$ did not stimulate luciferase activity from a transiently transfected ERE reporter in any of these cell lines. In addition to the presence of dominant negative splice variants, another explanation for our results is the predominant cytoplasmic localization of $\mathrm{ER} \alpha$ and ERß in the thyroid cancer cells and the lack $\mathrm{E}_{2}$ stimulation of redistribution of ER to the nucleus. Our immunofluorescent studies agree with a previous report that ER $\alpha$ is exclusively cytoplasmic following $\mathrm{E}_{2}$ treatment of WRO cells (22), but conflict with a report that ER $\alpha$ is cytoplasmic and nuclear in untreated KAT5 cells (60). It is possible that differences in KAT5 culture conditions account for these disparities between labs. It is generally believed that ER signaling involves ligand-activated translocation to nucleus (70), although ER $\alpha$ is also nuclear in the absence of ligand (71). Although a short splice variant of MTA1, i.e., MTA1s, was reported to sequester ER $\alpha$ in the cytoplasm of breast cancer cells (72), thus blocking transcriptional activity, we did not detect MTA1s in the thyroid cancer cell lines or in MCF-7 cells. Thus, we conclude that MTA1s expression does not provide a mechanism to account for either the predominant cytoplasmic localization of ER $\alpha$ in the three thyroid cancer cell lines, regardless of $\mathrm{E}_{2}$ treatment, or the lack of $\mathrm{E}_{2}$-induced reporter gene expression in the transiently transfected cells.

Other studies in WRO cells reported that $\mathrm{E}_{2}$ increased cell proliferation by activating GPR30 (22). GRP30 has been reported to convey estrogenic signaling in a variety of cell types, independent of ER expression (73). We detected low GPR30 mRNA expression in WRO relative to MCF-7 breast cancer cells and report for the first time that neither KAT5 nor NPA87 cells express GPR30. While GPR30 was reported not be a bone fide membrane ER, its role as a collaborator with ER $\alpha$ and ERß (23), remains to be resolved. $E_{2}$ was reported to activate MAPK signaling in KAT5 cells (27). Here, based on inhibitor studies, we demonstrated that the $\mathrm{E}_{2}$-induced proliferation of KAT5, NPA87, and WRO cells involved nongenomic ER activation of MAPK, PI3K, and G $\alpha$ proteins. $\mathrm{E}_{2}$ rapidly activates $\mathrm{PI} 3 \mathrm{~K} / \mathrm{AKT}$ and ERK1/2 in a variety of cell types (19). Our data demonstrating that knockdown of $\mathrm{ER} \alpha$ and ER 3 expression in KAT5 and WRO cells inhibited $\mathrm{E}_{2}$-induced phosphorylation of ERK1/2 implicates a role for both subtypes in ERK1/2 activation. The integration of non-genomic and genomic ER signaling pathways in breast cancer is complex (74) and is likely to be equally complex in thyroid cancer. Further experiments are required to elucidate the form(s) of ER, including splice variants and interactions of ERs with GPR30, and other plasma membrane receptors, e.g., EGFR, in thyroid cancer cells.

Despite the lack of nuclear ER $\alpha$ and ERß localization, $\mathrm{E}_{2}$ increased cathepsin $\mathrm{D}(C T S D)$ transcription in WRO cells and expression was inhibited by ICI and by siRNA-mediated knockdown of ER $\alpha$ and ERß. Cathepsin D is a classical $E_{2}$ target gene regulated by $\mathrm{Sp} 1-\mathrm{ER} \alpha$ promoter binding (75). Interestingly, the basal cathepsin D protein expression was higher in each of the 3 cell thyroid cancer cell lines than in MCF-7 cells. It is well-established that cathepsin D expression is elevated in thyroid tumors and correlates with disease aggression (76). Cathepsin D mRNA levels were unaffected by $E_{2}$ in KAT5 and NPA87 cells, likely reflecting cell linespecific gene responses to $\mathrm{E}_{2}$.

The expression of another classical $\mathrm{E}_{2}$ target gene, CCND1, cyclin D1 (77), was stimulated by $\mathrm{E}_{2}$ in all three thyroid cancer cell lines and co-treatment with ICI as well as siER $\alpha$ and siERß experiments revealed roles for ER $\alpha$ and $E R ß$ in regulating cyclin D1 transcription. $\mathrm{E}_{2}$ regulation of cyclin D1 transcription involved ER $\alpha$-Sp1 interaction (78) and AP-1-ER $\alpha$ or AP-1$\mathrm{ER} \alpha$ interaction (79). Thus, the induction of cyclin D1 transcription in response to $\mathrm{E}_{2}$ indicates intact genomic ER signaling in KAT5, NPA87, and WRO thyroid cancer cells.

Overall, this study provides evidence that although KAT5, WRO, and NPA87 thyroid cancer cells express ER $\alpha$ and ERß, genomic ER activity is reduced compared to that observed in MCF-7 breast cancer cells. Further, in agreement with previous reports $(22,27,28)$, we observed non-genomic $\mathrm{E}_{2}$ activation of ERK1/2 and cell proliferation. Clearly, additional studies are necessary to elucidate the roles of ER $\alpha$ and ERß and their splice variants in both transcriptional and non-genomic signaling activates in response to $\mathrm{E}_{2}$ and other ER ligands including SERMs in thyroid cancer. Such studies may lead to a new understanding of the pathogenesis of thyroid cancer and its female bias.

\section{Acknowledgements}

This work was funded in part by the Marsha and Randy Simoneaux Scholarship in Endocrine Tumor Biology and Norton Healthcare, Inc., Louisville, KY, to R.E.G. and NIH R01 DK53220 to C.M.K. The authors are grateful to Susan M. Dougherty for performing the luciferase assays, Dr Margarita M. Ivanova for providing the recombinant human ER $\alpha$ and ERß, and Krista A. Riggs for her help in Q-PCR. We thank Dr John Katzenellenbogen for generously providing the R,R-THC used in this study. We thank Dr Nalinie S. Wickramasinghe for her suggestions for improving this manuscript.

\section{References}

1. Correa P and Chen VW: Endocrine gland cancer. Cancer 75: 338-352, 1995.

2. Jemal A, Tiwari RC, Murray T, Ghafoor A, Samuels A, Ward E, Feuer EJ and Thun MJ: Cancer statistics, 2004. CA Cancer J Clin 54: 8-29, 2004.

3. Robbins J, Merino MJ, Boice JD Jr, Ron E, Ain KB, Alexander HR, Norton JA and Reynolds J: Thyroid cancer: a lethal endocrine neoplasm. Ann Intern Med 115: 133-147, 1991.

4. Yane K, Kitahori Y, Konishi N, Okaichi K, Ohnishi T, Miyahara H, Matsunaga T, Lin JC and Hiasa Y: Expression of the estrogen receptor in human thyroid neoplasms. Cancer Lett 84: 59-66, 1994.

5. Davies L and Welch HG: Increasing incidence of thyroid cancer in the United States, 1973-2002. JAMA 295: 2164-2167, 2006. 
6. Fassina AS, Rupolo M, Pelizzo MR and Casara D: Thyroid cancer in children and adolescents. Tumori 80: 257-262, 1994.

7. Cady B, Sedgwick CE, Meissner WA, Wool MS, Salzman FA and Werber J: Risk factor analysis in differentiated thyroid cancer. Cancer 43: 810-820, 1979

8. Ron E, Kleinerman RA, Boice JD Jr, Li Volsi VA, Flannery JT and Fraumeni JF Jr: A population-based case-control study of thyroid cancer. J Natl Cancer Inst 79: 1-12, 1987.

9. Manole D, Schildknecht B, Gosnell B, Adams E and Derwahl M Estrogen promotes growth of human thyroid tumor cells by different molecular mechanisms. J Clin Endocrinol Metab 86: 1072-1077, 2001.

10. Bonacci R, Pinchera A, Fierabracci P, Gigliotti A, Grasso L and Giani C: Relevance of estrogen and progesterone receptors enzyme immunoassay in malignant, benign and surrounding normal thyroid tissue. J Endocrinol Invest 19: 159-164, 1996.

11. Metaye T, Millet C, Kraimps JL, Aubouin B, Barbier J and Begon F: Estrogen receptors and cathepsin D in human thyroid tissue. Cancer 72: 1991-1996, 1993.

12. Nagy N, Camby I, Decaestecker C, Chaboteaux C, Gras T, Darro F, Rocmans P, Kiss R and Salmon I: The influence of L-triiodothyronine, L-thyroxine, estradiol-17beta, the luteinizinghormone-releasing hormone, the epidermal growth factor and gastrin on cell proliferation in organ cultures of 35 benign and 13 malignant human thyroid tumors. J Cancer Res Clin Oncol 125: 361-368, 1999

13. Inoue $\mathrm{H}$, Oshimo K, Miki H, Kawano $\mathrm{M}$ and Monden $\mathrm{Y}$ : Immunohistochemical study of estrogen receptors and the responsiveness to estrogen in papillary thyroid carcinoma. Cancer 72: 1364-1368, 1993

14. Heldring N, Pike A, Andersson S, Matthews J, Cheng G, Hartman J, Tujague M, Strom A, Treuter E, Warner M and Gustafsson JA: Estrogen receptors: how do they signal and what are their targets. Physiol Rev 87: 905-931, 2007

15. Weihua Z, Andersson S, Cheng G, Simpson ER, Warner M and Gustafsson JA: Update on estrogen signaling. FEBS Lett 546: $17-24,2003$

16. Klinge CM: Estrogen receptor interaction with co-activators and co-repressors. Steroids 65: 227-251, 2000.

17. Mazumdar A, Wang RA, Mishra SK, Adam L, BagheriYarmand R, Mandal M, Vadlamudi RK and Kumar R: Transcriptional repression of oestrogen receptor by metastasisassociated protein 1 corepressor. Nat Cell Biol 3: 30-37, 2001

18. Kumar R, Wang RA, Mazumdar A, Talukder AH, Mandal M, Yang Z, Bagheri-Yarmand R, Sahin A, Hortobagyi G, Adam L, Barnes CJ and Vadlamudi RK: A naturally occurring MTA variant sequesters oestrogen receptor-alpha in the cytoplasm. Nature 418: 654-657, 2002

19. Watson CS, Alyea RA, Jeng YJ and Kochukov MY: Nongenomic actions of low concentration estrogens and xenoestrogens on multiple tissues. Mol Cell Endocrinol 274: 1-7, 2007.

20. Pedram A, Razandi M and Levin ER: Nature of functional estrogen receptors at the plasma membrane. Mol Endocrinol 20: 1996-2009, 2006.

21. Filardo E, Quinn J, Pang Y, Graeber C, Shaw S, Dong J and Thomas P: Activation of the novel estrogen receptor $G$ protein-coupled receptor 30 (GPR30) at the plasma membrane. Endocrinology 148: 3236-3245, 2007.

22. Vivacqua A, Bonofiglio D, Albanito L, Madeo A, Rago V Carpino A, Musti AM, Picard D, Ando S and Maggiolini M: 17beta-estradiol, genistein, and 4-hydroxytamoxifen induce the proliferation of thyroid cancer cells through the groteincoupled receptor GPR30 1. Mol Pharmacol 70: 1414-1423, 2006

23. Levin ER: G Protein-coupled receptor 30: estrogen receptor or collaborator? Endocrinology 150: 1563-1565, 2009.

24. Egawa C, Miyoshi Y, Iwao K, Shiba E and Noguchi S: Quantitative analysis of estrogen receptor- $\alpha$ and $-\beta$ messenger RNA expression in normal and malignant thyroid tissues by real-time polymerase chain reaction. Oncology 61: 293-298, 2001

25. Dalla VL, Ramina A, Vianello S, Fassina A, Belvedere P and Colombo L: Potential for estrogen synthesis and action in human normal and neoplastic thyroid tissues. J Clin Endocrinol Metab 83: 3702-3709, 1998

26. Mizukami Y, Michigishi T, Nonomura A, Hashimoto T, Noguchi M and Matsubara F: Estrogen and estrogen receptors in thyroid carcinomas. J Surg Oncol 47: 165-169, 1991.
27. Zeng Q, Chen GG, Vlantis AC and van Hasselt CA: Oestrogen mediates the growth of human thyroid carcinoma cells via an estrogen receptor-ERK pathway. Cell Prolif 40: 921-935, 2007.

28. Chen GG, Vlantis AC, Zeng Q and van Hasselt CA: Regulation of cell growth by estrogen signaling and potential targets in thyroid cancer. Curr Cancer Drug Targets 8: 367-377, 2008.

29. O'Malley BW: A life-long search for the molecular pathways of steroid hormone action. Mol Endocrinol 19: 1402-1411, 2005.

30. Sun J, Meyers MJ, Fink BE, Rajendran R, Katzenellenbogen JA and Katzenellenbogen BS: Novel ligands that function as selective estrogens or antiestrogens for estrogen receptor-alpha or estrogen receptor-beta. Endocrinology 140: 800-804, 1999.

31. Yeh MW, Rougier JP, Park JW, Duh QY, Wong M, Werb Z and Clark OH: Differentiated thyroid cancer cell invasion is regulated through epidermal growth factor receptor-dependent activation of matrix metalloproteinase (MMP)-2/gelatinase A. Endocr Relat Cancer 13: 1173-1183, 2006.

32. Tyulmenkov VV, Jernigan SC and Klinge CM: Comparison of transcriptional synergy of estrogen receptors alpha and beta from multiple tandem estrogen response elements. Mol Cell Endocrinol 165: 151-161, 2000.

33. Ramsey TL, Risinger KE, Jernigan SC, Mattingly KA and Klinge CM: Estrogen receptor beta isoforms exhibit differences in ligand-activated transcriptional activity in an estrogen response element sequence-dependent manner. Endocrinology 145: 149-160, 2004.

34. Dougherty SM, Mazhawidza W, Bohn AR, Robinson KA, Mattingly KA, Blankenship KA, Huff MO, McGregor WG and Klinge CM: Gender difference in the activity but not expression of estrogen receptors alpha and beta in human lung adenocarcinoma cells. Endocr Relat Cancer 13: 113-134, 2006.

35. Livak KJ and Schmittgen TD: Analysis of relative gene expression data using real-time quantitative PCR and the 2(-Delta Delta C(T)) method. Methods 25: 402-408, 2001

36. Webb P, Lopez GN, Uht RM and Kushner PJ: Tamoxifen activation of the estrogen receptor/AP-1 pathway: potential origin for the cell-specific estrogen-like effects of antiestrogens. Mol Endocrinol 9: 443-456, 1995.

37. Paige LA, Christensen DJ, Gron H, Norris JD, Gottlin EB, Padilla KM, Chang CY, Ballas LM, Hamilton PT, McDonnell DP and Fowlkes DM: Estrogen receptor (ER) modulators each induce distinct conformational changes in ER alpha and ER beta. Proc Natl Acad Sci USA 96: 3999-4004, 1999.

38. De Friend DJ, Howell A, Nicholson RI, Anderson E, Dowsett M, Mansel RE, Blamey RW, Bundred NJ, Robertson JF and Saunders C: Investigation of a new pure antiestrogen (ICI 182780 ) in women with primary breast cancer. Cancer Res 54: 408-414, 1994

39. Pietras RJ and Marquez-Garban DC: Membrane-associated estrogen receptor signaling pathways in human cancers. Clin Cancer Res 13: 4672-4676, 2007.

40. Stauffer SR, Coletta CJ, Tedesco R, Nishiguchi G, Carlson K, Sun J, Katzenellenbogen BS and Katzenellenbogen JA: Pyrazole ligands: structure-affinity/activity relationships and estrogen receptor-alpha-selective agonists. J Med Chem 43: 4934-4947, 2000.

41. Meyers MJ, Sun J, Carlson KE, Marriner GA, Katzenellenbogen BS and Katzenellenbogen JA: Estrogen receptor-beta potencyselective ligands: structure-activity relationship studies of diarylpropionitriles and their acetylene and polar analogues. J Med Chem 44: 4230-4251, 2001

42. Herynk MH and Fuqua SAW: Estrogen receptor mutations in human disease. Endocr Rev 25: 869-898, 2004.

43. Klinge CM: Estrogenic control of mitochondrial function and biogenesis. J Cell Biochem 105: 1342-1351, 2008.

44. Abbondanza C, De FA, Nigro V, Medici N, Armetta I, Molinari AM, Moncharmont B and Puca GA: Characterization and epitope mapping of a new panel of monoclonal antibodies to estradiol receptor. Steroids 58: 4-12, 1993.

45. Wang Z, Zhang X, Shen P, Loggie BW, Chang Y and Deuel TF: Identification, cloning, and expression of human estrogen receptor-alpha36, a novel variant of human estrogen receptoralpha66. Biochem Biophys Res Commun 336: 1023-1027, 2005.

46. Wang Z, Zhang X, Shen P, Loggie BW, Chang Y and Deuel TF: A variant of estrogen receptor-alpha, hER-alpha36: transduction of estrogen- and antiestrogen-dependent membrane-initiated mitogenic signaling. Proc Natl Acad Sci USA 103: 9063-9068, 2006. 
47. Pink JJ, Wu SQ, Wolf DM, Bilimoria MM and Jordan VC: A novel $80 \mathrm{kDa}$ human estrogen receptor containing a duplication of exons 6 and 7. Nucleic Acids Res 24: 962-969, 1996.

48. Moore JT, McKee DD, Slentz-Kesler K, Moore LB, Jones SA, Horne EL, Su JL, Kliewer SA, Lehmann JM and Willson TM: Cloning and characterization of human estrogen receptor beta isoforms. Biochem Biophys Res Commun 247: 75-78, 1998.

49. Ivanova MM, Mattingly KA and Klinge CM: Estrogen receptor beta yield from baculovirus lytic infection is higher than from stably transformed Sf21 cells. Appl Microbiol Biotechnol 74 : 1256-1263, 2007.

50. Schlegel A, Wang C, Katzenellenbogen BS, Pestell RG and Lisanti MP: Caveolin-1 potentiates estrogen receptor alpha (ERalpha) signaling. caveolin-1 drives ligand-independent nuclear translocation and activation of ERalpha. J Biol Chem 274: 33551-33556, 1999

51. Pietras RJ, Marquez DC, Chen HW, Tsai E, Weinberg O and Fishbein M: Estrogen and growth factor receptor interactions in human breast and non-small cell lung cancer cells. Steroids 70 : 372-381, 2005

52. Klinge CM, Jernigan SC, Mattingly KA, Risinger KE and Zhang J: Estrogen response element-dependent regulation of transcriptional activation of estrogen receptors alpha and beta by coactivators and corepressors. J Mol Endocrinol 33: 387-410, 2004.

53. Frasor J, Danes JM, Komm B, Chang KC, Lyttle CR and Katzenellenbogen BS: Profiling of estrogen up- and downregulated gene expression in human breast cancer cells: insights into gene networks and pathways underlying estrogenic control of proliferation and cell phenotype. Endocrinology 144: 4562-4574, 2003.

54. Rochefort H, Chalbos D, Cunat S, Lucas A, Platet N and Garcia M: Estrogen regulated proteases and antiproteases in ovarian and breast cancer cells. J Steroid Biochem Mol Biol 76: 119-124, 2001

55. Veith FO, Capony F, Garcia M, Chantelard J, Pujol H, Veith F, Zajdela A and Rochefort H: Release of estrogen-induced glycoprotein with a molecular weight of 52,000 by breast cancer cells in primary culture. Cancer Res 43: 1861-1868, 1983.

56. Sherr CJ: Cancer cell cycles. Science 274: 1672-1677, 1996.

57. Sabbah M, Courilleau D, Mester J and Redeuilh G: Estrogen induction of the cyclin D1 promoter: involvement of a cAMP response-like element. Proc Natl Acad Sci USA 96: 11217-11222, 1999.

58. Filardo EJ, Quinn JA, Bland KI and Frackelton AR Jr: Estrogeninduced activation of Erk-1 and Erk-2 requires the $\mathrm{G}$ proteincoupled receptor homolog, GPR30, and occurs via transactivation of the epidermal growth factor receptor through release of HB-EGF. Mol Endocrinol 14: 1649-1660, 2000.

59. Lee ML, Chen GG, Vlantis AC, Tse GM, Leung BC and van Hasselt CA: Induction of thyroid papillary carcinoma cell proliferation by estrogen is associated with an altered expression of Bcl-xL. Cancer J 11: 113-121, 2005.

60. Zeng Q, Chen G, Vlantis A, Tse G and van Hasselt C: The contributions of oestrogen receptor isoforms to the development of papillary and anaplastic thyroid carcinomas. J Pathol 214: 425-433, 2008 .

61. Furlanetto TW, Nguyen LQ and Jameson JL: Estradiol increases proliferation and down-regulates the sodium/iodide symporter gene in FRTL-5 cells. Endocrinology 140: 5705-5711, 1999

62. Cho MA, Lee MK, Nam KH, Chung WY, Park CS, Lee JH, Noh T, Yang WI, Rhee Y, Lim SK, Lee HC and Lee EJ Expression and role of estrogen receptor (alpha) and (beta) in medullary thyroid carcinoma: different roles in cancer growth and apoptosis. J Endocrinol 195: 255-263, 2007.
63. Banu KS, Govindarajulu P and Aruldhas MM: Testosterone and estradiol have specific differential modulatory effect on the proliferation of human thyroid papillary and follicular carcinoma cell lines independent of TSH action. Endocr Pathol 12: 315-327, 2001

64. Hoelting T, Siperstein AE, Duh QY and Clark OH: Tamoxifen inhibits growth, migration, and invasion of human follicular and papillary thyroid cancer cells in vitro and in vivo. J Clin Endocrinol Metab 80: 308-313, 1995.

65. Freddie CT, Larsen SS, Bartholomaeussen M and Lykkesfeldt AE: The effect of the new SERM arzoxifene on growth and gene expression in MCF-7 breast cancer cells. Mol Cell Endocrinol 219: 27-36, 2004

66. Lewis JS and Jordan VC: Selective estrogen receptor modulators (SERMs): mechanisms of anticarcinogenesis and drug resistance. Mutat Res 591: 247-263, 2005.

67. Metivier R, Penot G, Carmouche RP, Hubner MR, Reid G, Denger S, Manu D, Brand H, Kos M, Benes V and Gannon F: Transcriptional complexes engaged by apo-estrogen receptoralpha isoforms have divergent outcomes. EMBO J 23: 3653-3666, 2004.

68. Penot G, Le PC, Merot Y, Grimaud-Fanouillere E, Ferriere F, Boujrad N, Kah O, Saligaut C, Ducouret B, Metivier R and Flouriot G: The human estrogen receptor-alpha isoform hERalpha46 antagonizes the proliferative influence of hERalpha66 in MCF7 breast cancer cells. Endocrinology 146: 5474-5484, 2005

69. Klinge CM: Estrogen receptor interaction with estrogen response elements. Nucleic Acids Res 29: 2905-2919, 2001.

70. Kumar V and Chambon P: The estrogen receptor binds tightly to its responsive element as a ligand-induced homodimer. Cell 55: $145-156,1988$

71. Green S, Kumar V, Krust A, Walter P and Chambon P: Structural and functional domains of the estrogen receptor. Cold Spring Harb Symp Quant Biol 51: 751-758, 1986.

72. Singh RR, Kaluarachchi K, Chen M, Rayala SK, Balasenthil S, $\mathrm{Ma} \mathrm{J}$ and Kumar R: Solution structure and antiestrogenic activity of the unique C-terminal, NR-box motif-containing region of MTA1s. J Biol Chem 281: 25612-25621, 2006.

73. Prossnitz ER and Maggiolini M: Mechanisms of estrogen signaling and gene expression via GPR30. Mol Cell Endocrinol 308: 32-38, 2009.

74. Silva CM and Shupnik MA: Integration of steroid and growth factor pathways in breast cancer: focus on signal transducers and activators of transcription and their potential role in resistance. Mol Endocrinol 21: 1499-1512, 2007.

75. Wang F, Porter W, Xing W, Archer TK and Safe S: Identification of a functional imperfect estrogen-responsive element in the 5'promoter region of the human cathepsin D gene. Biochemistry 36: 7793-7801, 1997.

76. Leto G, Tumminello FM, Crescimanno M, Flandina C and Gebbia N: Cathepsin D expression levels in non-gynecological solid tumors: clinical and therapeutic implications. Clin Exp Metastasis 21: 91-106, 2004.

77. Pestell RG, Albanese C, Reutens AT, Segall JE, Lee RJ and Arnold A: The cyclins and cyclin-dependent kinase inhibitors in hormonal regulation of proliferation and differentiation. Endocr Rev 20: 501-534, 1999.

78. Castro-Rivera E, Samudio I and Safe S: Estrogen regulation of cyclin D1 gene expression in ZR-75 breast cancer cells involves multiple enhancer elements. J Biol Chem 276: 30853-30861, 2001.

79. Liu M-M, Albanese C, Anderson CM, Hilty K, Webb P, Uht RM, Price RH Jr, Pestell RG and Kushner PJ: Opposing action of estrogen receptors alpha and beta on cyclin D1 gene expression. J Biol Chem 277: 24353-24360, 2002. 